\title{
Songs of the Bailang \\ a new transcription with etymological commentary
}

\author{
Nathan W. Hill ${ }^{1}$
}

\section{Introduction}

The 'Song of Bailang' (白狼歌) are three poems in a Trans-Himalayan ${ }^{2}$ language transliterated with Chinese characters and translated into Chinese during the Han dynasty (specifically 58-75 CE). Apart from Chinese, Bailang is thus the earliest attested language of this family. The three songs are currently preserved in the 後漢書 Hou Hanshu (juan 86, pp. 2856-57). In this source the text of the songs is reported first in Chinese translation, in four-character lines, alternating with the original text in phonetic transcription, also in four-character lines and in smaller characters. The Hou Han shu, was compiled between 433 and 445. However, a note in the commentary to the Hou Han shu by Li Xian 李賢 (677 CE) makes clear that the latter's source was a somewhat earlier work, the Dongguan Hanji 東觀漢記, compiled between ca. 70 and $225 \mathrm{CE}$. According to Li Xian, in the Dongguan Hanji the text of the songs was in reversed order, with the transcription given as main text and the translation inserted as interlinear annotation (see Li Xian's note in Hou Han shu, juan 86, p. 2867). ${ }^{3}$

In 1979, making extensive use of previous research, W. S. Coblin published a study of these songs. In addition to transcribing the poems into Roman letters following the reconstructions of Chinese available at that time, Coblin translated the context in the Hou Hanshu in which the Chinese versions of the poems appear, translated the Chinese versions of the poems into English, and provided comparanda to Proto-Lolo-Burmese and Proto-Tibeto-Burman reconstructions available at that time. Ma \& Dai (1982) make further cognate proposals and does Zhengzhang (1993), the latter particularly making

1 I would like to acknowledge the generous support of the European Research Council for supporting this research, under the auspices of 'Beyond Boundaries: Religion, Region, Language and the State' (ERC Synergy Project 609823 ASIA). This paper was has also benefited from comments I received from Antonello Palumbo, Guillaume Jacques, Laurent Sagart, and Stefano Zachetti.

2 As a geographic term unburdened by strong implications regarding the place of Chinese on the Stammbaum, 'Trans-Himalayan' has advantages over its competitors 'Sino-Tibetan' and 'Tibeto-Burman' (cf. van Driem 2014).

3 The priority of the Bailang text contradicts Coblin's (and previous researchers') hypothesis that the attested Bailang version is a translation from Chinese (1979: 196-197). 
comparisons to Written Burmese. Advances in both Chinese historical phonology and comparative Trans-Himalayan linguistics more than warrant a renewed study of these poems. ${ }^{4}$ In 2008, Christopher Beckwith undertook a study that aimed to reevaluate these songs in light of recent progress in Chinese historical linguistics. Despite the many insights of his contribution, Beckwith's reconstructions are not methodologically explicit and hence not easily verifiable.

The study here proposes to make a new transcription of the Bailang songs, incorporating the contributions of Coblin (1979) and Beckwith (2008). Currently one has a choice of easy to use Old Chinese reconstructions that incorporate the six-vowel hypothesis of Old Chinese vocalism. Schuessler (2009) produces a 'minimal Old Chinese', which aims to reflect the opinio communis in its reconstructions; he also offers a 'later Han' reconstruction. In contrast to Schuessler's conservatism, Baxter \& Sagart (2014a and b) offer a 'new reconstruction', which self consciously incorporates controversial hypotheses and relies on a much broader set of data than previous reconstructions. ${ }^{5}$ Broadly speaking the new elements of Baxter \& Sagart's reconstructions are relevant to a very early phase of Chinese linguistic history. For those, like myself, who are broadly sympathetic to Baxter \& Sagart's reconstructions, it is easy to conceptualize their 'new reconstruction' as an older phase of Old Chinese and to see Schuessler's 'minimal' reconstruction as a more recent phase of Old Chinese. Because the Bailang Song's are of early Han provenance, Schuessler's Old Chinese reconstruction provides the more useful point of departure for their study. Thus, in discussion of the pronunciation of the transcriptional Chinese dialect or of the Bailang language itself, I cite Old and Han Chinese from Schuessler (2009). ${ }^{6}$ Because of its elegance and explicitness, I cite Middle Chinese from Baxter (1992). ${ }^{7}$ When

4 Coblin relied on Li $(1971,1974-5)$ for Chinese and for Proto-Lolo-Burmese and Proto-Tibeto-Burman on Benedict (1972), Matisoff (1972), Bradley (1975), Thurgood (1974), Okrand (1974).

5 The system of Baxter \& Sagart has not met with universal endorsement. Positive reviews include G. Starostin 2015, Goldstein 2015, and Hill 2017 'Review'. Negative reviews include Schuessler 2015, Ho 2016, and Harbsmeier 2016. On the one hand many criticisms apply mutatis mutandis to all six vowel systems (Ho 2016, esp. pp. 183-184) or even to all efforts in historical linguistics (Harbsmeier 2016, esp. pp. 484-487). On the other hand some criticisms concern details only (Schuessler 2015). Replies to the negative reviews are in press.

6 To allow the reader to concentrate on real points of disagreement rather than orthographic matters, I employ some of Baxter \& Sagart's (2014b) orthographic conventions in the writing of Schuessler's Old Chinese. In particular, Old Chinese type A syllables are here marked with pharyngealization ( $(5)$ and the origin of the qusheng tone is written ubiquitously as -s. When Baxter \& Sagart disagree with Schuessler on a matter of substance I duly record this in the footnotes.

7 An inconvenience of this combination of sources, is that the symbol 'a' diverges in meaning among these 
citing Old Chinese for etymological comparisons, rather than as a transcription of Bailang words, the most archaic stage of this language is most relevant, consequently in this context I employ Baxter \& Sagart's (2014b) reconstructions.

\section{The Chinese version}

Before attempting a phonological reconstruction of the Bailang versions of the songs, it is helpful to learn what the Chinese version tells about the pronunciation of Chinese at the time of songs' composition. The poems rhyme in Chinese and these rhymes provide information on Chinese pronunciation.

I provide each poem in Chinese with Coblin's translation. ${ }^{8}$ The rhyme word of each line is given in Old Chinese, Han Chinese, and Middle Chinese reconstructions, together with a reference number for Schuessler (2009) and Karlgren (1957). For example, the rhyme word of the second line is 意, so it is annotated OChi. Pəks $>$ Han Chi. Piə ${ }^{c}>$ MChi. 'iH; its rhyme group in Schuessler (2009) is 05-10 and its reference number in Karlgren (1957) is 0957a.

\section{Poem 1}

\begin{tabular}{|c|c|c|c|}
\hline 1. 大漢是治 & $\begin{array}{l}{ }^{9} \text { drə }>\text { dì }>\text { dri } \\
\text { drəs }>\text { dij }^{c}>\text { driH }\end{array}$ & $04-30 / 0976 z$ & The great Han is in good order, \\
\hline 2. 與天合意 & 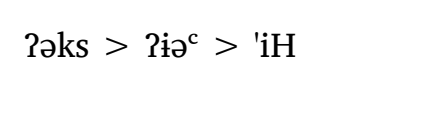 & 05-10/0957a & $\begin{array}{l}\text { Together with Heaven it unites its } \\
\text { intention. }\end{array}$ \\
\hline 3. 史譯平端 & ${ }^{10} t^{\varsigma}$ on $>$ tuan $>$ twan & $25-24 / 0168 d$ & $\begin{array}{l}\text { The officials and translators are just } \\
\text { and upright, }\end{array}$ \\
\hline 4. 不從我來 & ${ }^{11} \mathrm{r}$ `ək $>$ lə > loj & 05-22/0944a & $\begin{array}{l}\text { They did not, pursuing us, cause us } \\
\text { to come. }\end{array}$ \\
\hline 5. 聞風向化 & $\begin{array}{l}{ }^{12} \mathrm{gr}^{\mathrm{s}} \mathrm{Ois}>\mathrm{huæi}^{\mathrm{c}}>\mathrm{huæ}^{\mathrm{c}}> \\
\text { xwaeH }\end{array}$ & 19-08/0019a & $\begin{array}{l}\text { Having heard the (winds }=\text { ) } \\
\text { customs and faced toward the } \\
\text { (changes }=\text { ) civilizing influences, }\end{array}$ \\
\hline 6. 所見 & ləks $>\mathrm{j}^{\mathrm{c}}>\mathrm{yiH}$ & 05-17/0954a & what we have seen is (strange, \\
\hline
\end{tabular}

three phases. In order to obviate this situation, I replace 'a' with -a- for Old and Middle Chinese and 'a' with 'æ' for Han Chinese.

8 Lung (2011: 8-15) also translates the Chinese text into English.

9 Baxter \& Sagart (2014b) reconstruct 治 *C.lrə.

10 Baxter \& Sagart (2014b) reconstruct 端 * $\mathrm{t}^{\mathrm{f}} \mathrm{or}$.

11 Baxter \& Sagart (2014b) reconstruct 來 *mə.r ${ }^{\Upsilon} ə k$.

12 Baxter \& Sagart (2014b) reconstruct 化 * $\mathrm{q}^{\text {whs }}$ raj-s. 
extraordinary $=$ ) wonderful

7. 多賜繒布 $\mathrm{p}^{\mathrm{a}} \mathrm{as}>\mathrm{pa}^{\mathrm{c}}>\mathrm{puH}$

01-67/0102j

8. 甘美酒食 ${ }^{13} \mathrm{~s}$-ləks $>\mathrm{ziə}^{\mathrm{c}}>\mathrm{zijH}$

05-19/0921a

9. 昌樂肉飛 ${ }^{14}$ pəi $>$ pui $>$ pjij

10. 屈申悉備 $b r ə k s ~>b i \partial^{c}>b \dot{i}^{c}>b i j H$

11. 蠻夷貧薄 $\mathrm{b}^{\complement} \mathrm{ak}>\mathrm{bak}>\mathrm{bak}$

12. 無所報嗣 $\mathrm{s}-\mathrm{l} ə \mathrm{~s}>\mathrm{zi}^{\mathrm{c}}>\mathrm{ziH}$

13. 願主長壽 du? $>$ dźu ${ }^{b}>d z y u w X$

14. 子孫昌熾 $\mathrm{t}^{\mathrm{h}} \mathrm{\partial ks}>\mathrm{t} \mathrm{s}^{\mathrm{h}} \partial^{\mathrm{c}}>\mathrm{tsyhiH}$ 01-67/0771p

04-53/0972k

$13-22 / 1090 \mathrm{~g}$

05-13/09201
They have manifoldly given us silk cloth

and sweet and (beautiful =) fine wine and food.

In splendid happiness (our flesh flies $=$ ) we are elated'

Whether we are (bending $=$ ) declining or (stretching out $=$ ) advancing, in all cases we are provided for.

We, the barbarians, being poor and (thin $=$ ) impoverished, have nothing to give in repayment We wish for the ruler longevity And that his sons and grandsons shall be splendid and glorious.

\section{Poem 2.}

1. 蠻夷所處 ${ }^{15} \mathrm{k}-\mathrm{l} a \mathrm{a}>\mathrm{tś}^{\mathrm{b}}{ }^{\mathrm{b}}>\mathrm{tsyhoX}, \mathrm{tsyhoH}$

2. 日人之部 $\mathrm{b}^{\mathrm{c}} \mathrm{O}$ ? $>\mathrm{bo}^{\mathrm{b}}>\mathrm{buwX}$

3. 慕義向化 ${ }^{16} \mathrm{gr}^{\mathrm{s}} \mathrm{oih}>\mathrm{huæi}^{\mathrm{c}}>\mathrm{hua}^{\mathrm{c}}>\mathrm{xwaeH}$

4. 歸日出主 to? $>$ tśo $^{\mathrm{b}}>\mathrm{tsyuX}$

5. 聖德深恩 ${ }^{\text {` }}$ ’n $>$ ? 2 n $>$ 'on 01-18/0085a The place where we, the barbarians, dwell

$04-61 / 0999 \mathrm{z}$ (is) the sector whee the sun (enters $=$ ) sets.

19-08/0019a Longing for righteousness and facing toward the civilizing influence,

10-19/0129a we (return to $=$ ) commit ourselves to the ruler of (the place where) the sun comes out (i.e. the Chinese emperor)

32-09/0370j With sagely virtue and deep kindness

13 Baxter \& Sagart (2014b) reconstruct 食 *s-m-lək-s.

14 Baxter \& Sagart (2014b) reconstruct 飛 *Cə.pə[r].

15 Baxter \& Sagart (2014b) reconstruct 處 *t. $q^{\text {ha }}$ ?.

16 See note 12 . 
6. 與人富厚 $\mathrm{g}_{\mathrm{c}}^{\mathrm{o}} \mathrm{P}>\mathrm{go}^{\mathrm{b}}>\mathrm{huwX}$

7. 冬多霜雪 sot $>$ syæt $>$ sjwet

8. 夏多和雨 ${ }^{17} w a ?>w^{b}>$ hjuX, hjuH

9. 寒溫時適 tek $>$ tśek $>$ tsyek

10. 部人多有 ${ }^{18} w ə ?+w u \partial^{b}>w \partial^{b}>$ hjuwX

11. 涉危歷險 ${ }^{19} \mathrm{~g} \mathrm{ram} ?>$ hiæm $>$ xjaemX j̣ram? $>$ hiam $>$ xjemX

12. 不遠萬里 $\mathrm{r} \partial \mathrm{P}>\mathrm{li}^{\mathrm{b}}>\mathrm{li}^{\mathrm{b}}>\mathrm{liX}$

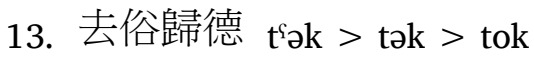

14. 心歸慈母 $\operatorname{mə}>>$ m $\partial^{b}>$ muwX

\section{Poem 3}

1. 荒服之外 $\mathrm{j}^{\mathrm{ws}}$ ats $>$ yuas $>$ ngwajH

2. 土地墝埆 $\mathrm{k}^{\mathrm{h} s}$ rok $>\mathrm{k}^{\mathrm{h}}$ rok $>$ khaewk

3. 食肉衣皮 bai $>$ biai $>$ bie $>$ bje

4. 不見鹽穀 $k^{\S}$ ok $>$ kok $>$ kuwk

5. 吏譯傳風 pəm $>$ puəm $>$ pjuwng

6. 大漢安樂 $\mathrm{yr}^{\mathrm{s} a u k s}>\mathrm{yæu}^{\mathrm{c}}>$ ngaewH
$10-07 / 0114 a$ together with other people he is wealthy and (think $=$ ) affluent (i.e. he shares his wealth with others).

$22-18 / 0297$ an winter there is much front and snow;

$01-26 / 0100 \mathrm{a}$ in summer there is much harmonious rain.

07-12/0877s The times of cold and warmth are (suitable) in proper balance,

04-17/0995o and the tribal people (manifoldly possess $=$ ) have plenty

36-06/0613f Having traversed dangers and passed through perils,

04-35/0978a We have not considered ten thousand li to be (too) far.

05-12/0919k Departing from (or: 'casting aside') the vulgar and (returning $=$ ) turning to virtue,

04-64/0947a our hearts return to the loving mother.

22-08/0322a Beyond the huang-fu region

$11-02-/ 1225-$ the soil is stony and hard.

18-16/0025a We eat meat and wear skins,

$11-03 / 1226 \mathrm{~h}$ and we do not see salt or grain.

36-26/0625h The officials and translators have transmitted the (winds $=$ ) news,

17-08/1125a and the great Han is peaceful and

17 Baxter \& Sagart (2014b) reconstruct 雨 ${ }^{*} \mathrm{C} . \mathrm{G}^{\mathrm{w}}(\mathrm{r}) \mathrm{a}$ ?.

18 Baxter \& Sagart (2014b) reconstruct 有 * $[\mathrm{G}]^{\mathrm{w}}$ ə?

19 Baxter \& Sagart (2014b) reconstruct 險 ${ }^{*} \mathrm{q}^{\mathrm{h}} \mathrm{r}[\mathrm{a}] \mathrm{m}$ ? for both readings, but the meaning of the notation [a] differs for the two MChi. readings, viz. xjaemX ( $<{ }^{*} \mathrm{q}^{\mathrm{h}}$ ram? or ${ }^{*} \mathrm{q}^{\mathrm{h}}$ rom?) and xjemX ( $<{ }^{*} \mathrm{q}^{\mathrm{h}}$ ram? or * $\mathrm{q}^{\mathrm{h}} \mathrm{rem}$ ). Still, the fact that OChi. *Kram can yield both MChi. Kjaem and Kjem is prime facie a violation of Ausnahmslosigkeit, albeit one the authors are aware of (see Baxter 1992: 539). Presumably the same issues also stimulate Schuessler to reconstruct two MChi. readings to only one OChi. source. 
happy.

7. 攜負歸仁 $\operatorname{nin}>\operatorname{nin}>$ nyin

8. 觸冒險狹 $g^{\mathrm{s}}$ ep $>$ gep $>$ heap

9. 高山岐峻 suns $>\operatorname{suin}^{\mathrm{c}}>\operatorname{swinH}$

10. 緣崖 石 dak > dźæk > dzyek

11. 木薄發家 $\mathrm{kr}^{\mathrm{s}} \mathrm{a}>\mathrm{kæ}>\mathrm{kae}$

12. 百宿到洛 $\mathrm{r}^{\mathrm{s}} \mathrm{ak}>\mathrm{lak}>\mathrm{lak}$

13. 父子同賜 sleks $>\operatorname{sie}^{\mathrm{c}}>\mathrm{sjeH}$

14. 懷抱匹帛 brak $^{\mathrm{s}}>$ bæk $>$ baek

15. 傳告種人 $\operatorname{nin}>\operatorname{nin}>$ nyin

16. 長願臣僕 $b^{\S}$ ok $>$ bok $>$ bowk, buwk 32-28/0388f Leading by the hand and carrying on our backs (our dependents), we (return to $=$ ) turn to humaneness.

35-03/0630e We have encountered and braved precipitous gorges.

$34-23 / 0468 z \quad$ The high mountains are steep and dangerous;

02-17/0795a We have followed along the edges of cliffs and boulders(?)

01-11/0032a (From) the tree thickets we led forth our families,

02-01/0766k And in one hundred overnight stops we have reached Lo-yang.

08-12/0850t Fathers and sons (in the same way $=$ ) altogether have been given (gifts);

02-38/0782f they cherish and embrace rolls of silk.

32-28/0388a They transmit (the news) and tell their fellow tribesmen,

$11-23 / 1211 \mathrm{~b}$ and long desire to be subjects and servants.

\subsection{Analysis of the Chinese rimes}

The three Chinese poems rhyme, generally in something approaching couplets, but the pattern is imperfect in all three.

The first poem does not rime particularly well in Old Chinese (治 *drə(s), 意 *2əoks, 端

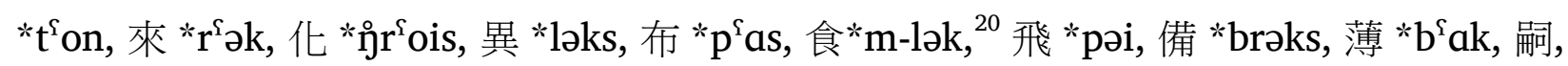
*s-ləs, 壽 *du?, 熾 * $\mathrm{t}^{\mathrm{h}}$ əks). The result in Han Chinese is better, but still not particularly

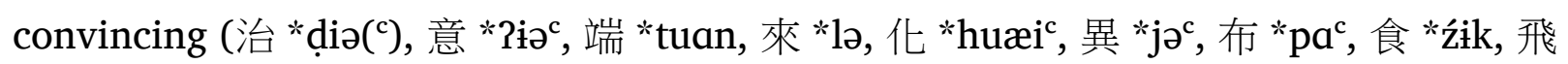

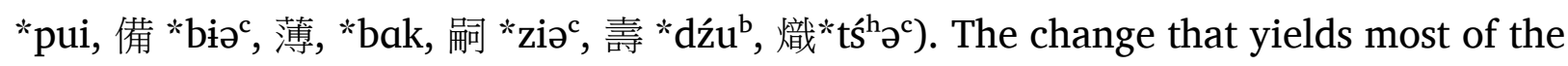
improvement is final cluster simplification (see comm. to $4 \mathrm{~b}$ ). I suspect that with velars

20 The character 食 has two readings zyik < *m-lək 'eat' and zih < *s-ləks 'feed'. Coblin (1979: 182) translates 'food' and gives the reading zyik (dźjzk in Li Fang-Kuei's system used by Coblin). 
this took the form *-ks $>-\mathrm{x}>-\mathrm{h}$ (Baxter 1992: 568). The change of $-\mathrm{s}>-\mathrm{h}$ improves things further (Baxter 1992: 578) as does a reminder that 來 irregularly lost its velar final already in the later strata of the Odes (Baxter \& Sagart 2014a: 230-231); it may be confidently read as * $\mathrm{r}^{\mathrm{f} \partial}$ rather than * $\mathrm{r}^{\mathrm{f}} \mathrm{\partial k}$. The rhyme words (治 *drə(h), 意 * $2 \partial h$, 端 * $\mathrm{t}^{\mathrm{f}}$ on,

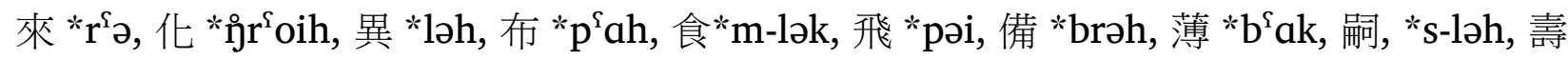
*du?, 熾 * $\mathrm{t}^{\mathrm{h}} \mathrm{\partial h}$ ) now yield a pattern AAXAXAXXXAXAXA which is still rather unimpressive. $^{21}$

The second poem rhymes equally well (or poorly) whether in Old Chinese (處 *k-la?, 部

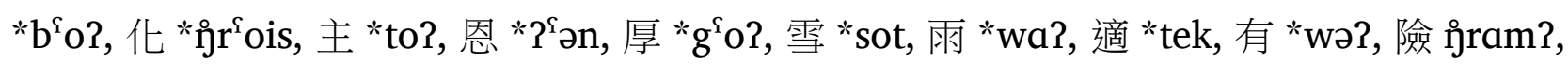
里 rə?, 德 $\mathrm{t}^{\mathrm{f}} \mathrm{rk}$, 母 mə2) or Han Chinese (處 *tśa $\mathrm{a}^{\mathrm{b}}$, 部 *bo ${ }^{\mathrm{b}}$, 化 *huæi $\mathrm{i}^{\mathrm{c}}$, 主 *tśo ${ }^{\mathrm{b}}$, 恩 *?ən, 厚 *go ${ }^{\mathrm{b}}$, 雪 *syæt, 雨 * ${ }^{*} a^{\mathrm{b}}$, 適 *tśek, 有 *wuə ${ }^{\mathrm{b}}$, 險 *hiæm / *hiam, 里 *liə ${ }^{\mathrm{b}}$, *德 tək, *母 mə ${ }^{\mathrm{b}}$ ). The pattern in either case is ABXBXBXAXCXCXC.

The third poem rhymes slightly better in Old Chinese (外 * $\mathrm{y}^{\mathrm{ws}} \mathrm{ats}$, 埆 * $\mathrm{k}^{\mathrm{h}} \mathrm{rok}$, 皮 *bai, 穀

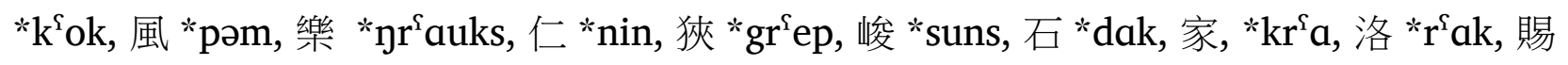
*sleks, 帛 *brak, 人*nin, 僕 * $\mathrm{b}^{\mathrm{s}} \mathrm{ok}$ ) than it does in Han Chinese (外 * yuas, 埆 * $k^{\mathrm{h}}$ rok, 皮 *biai, 穀 *kok, 風 *puəm, 樂 *yæu ${ }^{\mathrm{c}}$, 仁 *nin, 狹 *gep, 峻 *suinc, 石 *dźæk, 家 *kæ, 洛 *lak, 賜 * $\operatorname{sie}^{\mathrm{c}}$, 帛 *bæk, 人, *nin, 僕*bok), but the pattern is not particularly clear in either

21 This pattern can be improved slightly to AABABAXXXAXAXA by seeing 端 * $\mathrm{t}^{\mathrm{s}}$ on $>$ *tuan as rhyming with 化 * ${ }^{\mathrm{j}} \mathrm{r}^{\mathrm{r}} \mathrm{ois}>{ }^{*} \mathrm{huæi}^{\mathrm{c}}$. Allowing for this rhyme requires two or three hypotheses. First, that 'rcoloring' (Baxter 1992: 573-574) had not taken place; an assumption which the rhyming of the third Chinese poem proves. Second, we must follow Baxter \& Sagart (2014b) in reconstructing *-r in 端 and further supposing that *-r changed to -i in the eastern dialect of the capital (Baxter \& Sagart 2014a: 264271). Also in support of this hypothesis is the apparent rhyming in the second poem of 洗 with 尼 and of 藩 with 螺 and 漓 (vide infra). The third hypothesis is necessary if one prefers Baxter \& Sagart reconstruction of 化 as * $\mathrm{q}^{\text {whs }}$ rais, with the main vowel *a-, to Schuessler's * $\mathrm{pr}^{\mathrm{s}}$ ois, with the main vowel *-o-, a rhyme of ${ }^{*}$-wa- with original *-o- shows that *-o- had broken into *-ua- before acutes ('rounding diphthongization', see Baxter 1992: 566-567) by the time this poem was written. The comparison of the Bailang word 螺 *rsoi > luai 雨 'rain' (22d) with Bur. ø rwā 'rain', etc. confirms that this change took place in the Chinese transcriptional dialect, which is no surprise since the much earlier 左傳 Zuozhuan and 楚辭 Chuci already show evidence of rounding dipthongization (Baxter \& Sagart 2014a: 252, 255), it would be surprising if rounded vowels before acutes had not dipthongized in the language of these poems.

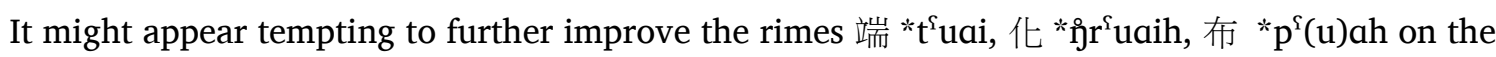
basis of the change ${ }^{* \varsigma}$ ai $>{ }^{\complement}$ a (Baxter \& Sagart 2014: 256 esp. n. 60 on p. 399, p. 268). However, such a move is not permissible because the Middle Chinese outcomes of OChi. *-`ai only merges with $-{ }^{*} \mathrm{a} a$ in certain environments (environments that 布 does not satisfy), and only after *r-coloring (Baxter 1992: 570-571), a change that we have already determined had not yet occurred in the Bailang transcriptional dialect. 
stage of the language. Final cluster simplification (particularly the change *ats $>$ aih, see Baxter 1999: 309) again improves things a bit. The pattern of the rhyme words (now 外

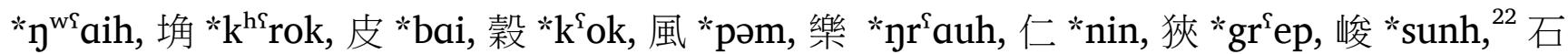

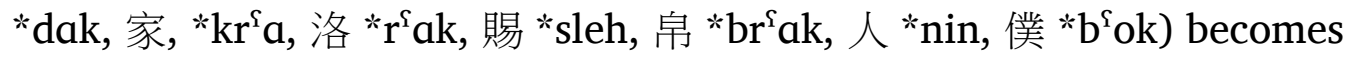

ABABXXCXXDXDXDCB. This pattern, such as it is would be obliterated by 'r-coloring', so we can conclude that this change had not yet taken place (Baxter 1992: 573-574)

In sum, it is possible to conclude that the Chinese transcriptional dialect of the Bailang songs had not yet undergone 'r-coloring', but had undergone 'final cluster simplification' and probably also 'rounding dipthongization' (see note 21).

\section{The Bailang version}

The presentation of the Bailang version given below follows the conventions used above for the Chinese rhyme words, but in the Bailang case the various pieces of information, viz. Old Chinese, Han Chinese, Middle Chinese, Schuessler reference, Karlgren reference, are given for each character of the text. The Bailang text is aligned with its Chinese translation character by character, a process that on occasion requires an inversion of two Chinese characters. I usually follow Coblin's (1979) suggestions in this regard; all cases are noted explicitly. The Chinese words are also rendered into English.

\section{Poem 1}

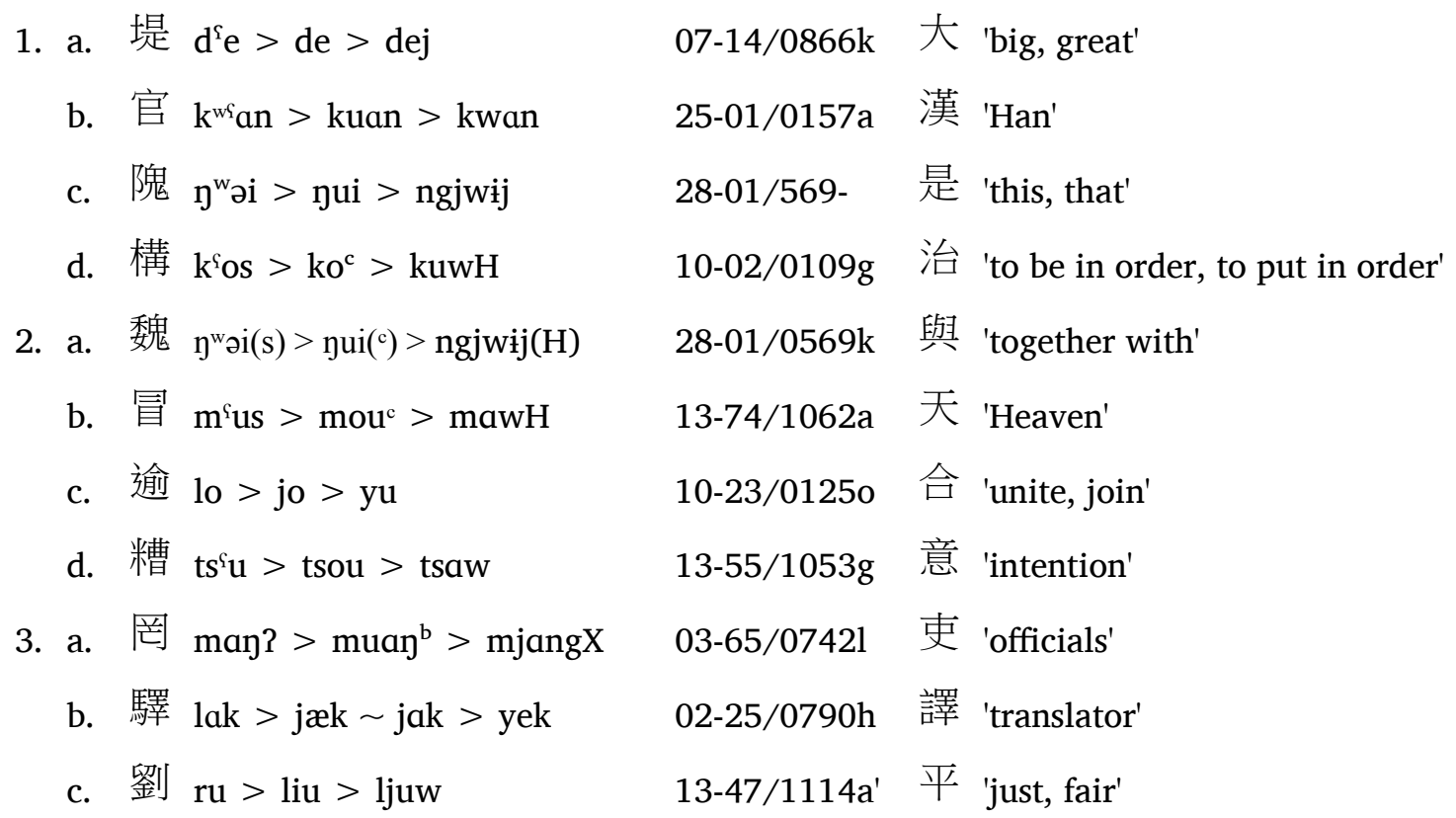

22 Han 峻 *suin ${ }^{c}$ may however seem like an improvement over Old Chinese 峻 *suns, because in the more recent reading the word can be understood to rhyme with 仁 *nin and 人*nin. 

d. 脾 be $>$ bie $>$ bjie
07-29/0874h 端 'honest'

4. a. 旁 $b^{\varsigma} a y>b a \eta>b a n g$,

03-57/0740f' 從 'pursue, follow'

$\mathrm{p}^{\uparrow}$ ay $>$ pæy > paeng

b. 莫 $\mathrm{mr}^{\mathrm{s}} \mathrm{ak}>\mathrm{mæk}>$ maek

02-40/0802a 不 'not'

$\mathrm{m}^{\mathrm{s}} \mathrm{ak}>\mathrm{mak}>\mathrm{mak}$

$\mathrm{m}^{\mathrm{s}} \mathrm{aks}>\mathrm{ma}^{\mathrm{c}}>\mathrm{muH}$

c. 支 $k e>$ kie $>$ tśe $>$ tsye

07-03/0864a 我 'we, us'

d. 留 $\mathrm{ru}>$ liu $>$ ljuw

13-47/1114p 來 'cause to come'

5. a. 徵 $\operatorname{drə\eta }>\operatorname{din}>$ dring

06-11/0891a 聞 'hear'

$$
\begin{aligned}
& \text { trəy }>\text { țin }>\text { tring } \\
& \text { trə? }>\text { ți } a^{b}>\operatorname{triX}
\end{aligned}
$$
b. 衣 $2 \partial i(s)>P i i(c)>\operatorname{jij}(H)$
c. 隨 $\mathrm{s}-\mathrm{wai}^{23}>$ zyæi $>$ zjwe
d. 旅 $\mathrm{ra}>\mathrm{lia}^{\mathrm{b}}>\mathrm{ljoX}$

27-05/0550a 風 '(wind $=$ ) custom'

19-09/0011g 向 'face toward'

01-55/0077a 化 '(change =) civilizing influence'

23 Baxter \& Sagart (2014b) reconstruct *sə.loj. 
6. a. 知 tre $>$ ție $>$ trje

b. 唐 $\quad \mathrm{l}^{\mathrm{s}}$ ay $>\mathrm{da \eta}>\mathrm{dang}^{24}$

c. 桑 $s^{\S}$ an $>$ san $>$ sang

d. 艾 $\mathrm{\eta}^{\mathrm{s}}$ as $>$ gas $>$ ngajH

yas $>$ nias $>$ ngjojH $^{25}$

7. a. 邪 ja $>$ jæ $>$ yae

s-la $>$ ziæ $>$ zjae

s-la $>$ zia $>$ zjo $^{26}$

b. 毗 bi $>$ bi $>$ bjij

c. (reading unknown)

d. 䋠 $\mathrm{p}^{\mathrm{s}} \mathrm{a}$ ? $>\mathrm{pa}^{\mathrm{b}}>\mathrm{puX}$

8. a. 推 $\mathrm{t}^{\mathrm{h} \mathrm{u}} \mathrm{uj}>\mathrm{t}^{\mathrm{h}} \mathrm{u} \mathrm{i}>\mathrm{thwoj}$

$\mathrm{t}^{\mathrm{h}} \mathrm{uj}>\mathrm{ts}^{\mathrm{h}} \mathrm{ui}>\mathrm{tsyhwij}$

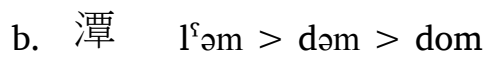

c. 僕

$\mathrm{b}^{\mathrm{s}} \mathrm{ok}>$ bok $>$ bowk, buwk

$\mathrm{p}^{\mathrm{hs}}$ ok $>\mathrm{p}^{\mathrm{h}} \mathrm{ok}>$ phuwk

d. 遠 wans $>$ wan $^{\mathrm{c}}>$ hjwonH

wan? $>$ wan $^{\mathrm{b}}>$ hjwonX $^{28}$

9. a. 拓 $\mathrm{t}^{\mathrm{hs}} \mathrm{ak}>\mathrm{t}^{\mathrm{h}} \mathrm{ak}>$ thak

b. 拒

ga? $>$ gia $^{\mathrm{b}}>$ gjoX

kwa? $>\mathrm{kya}^{\mathrm{b}}>\mathrm{kjuX}$

c. 蘇 $\quad s y^{\S} \mathrm{a}>\mathrm{sa}>\mathrm{su}$

d. 便

bens $>$ biæn $^{c}>$ bjienH

ben $>$ biæn $>$ bjien

ben? $>$ biæn $^{\mathrm{b}}>$ bjien $^{29}$

10. a. 局 gok $>$ guok $>$ gjowk

b. 後 $\mathrm{f}^{\complement} \mathrm{os}^{30}>\mathrm{yo}^{\mathrm{c}}>$ huwH

$\mathrm{h}^{\mathrm{s}} \mathrm{O}$ ? $>\mathrm{yo}^{\mathrm{b}}>$ huwX 07-13/0863a 所 relative clause nominalizer

03-12/0700a 見 'see'

03-53/0704a 奇 'strange'

21-10/0347c 異 'different'

01-47/0047a 多 'much, manifoldly'

26-38/0566u 賜 'give'

38-11/0658- 繒 'silk'

01-67/0102- 布 'cloth'

28-11/0575a' 美 'beautiful, fine ${ }^{27}$

38-16/0646b 甘 'sweet'

11-23/1211b 酒 'wine'

25-15/0256f 食 'food'

02-17/0795m 昌 'splendid, bright'

01-19/0095i 樂 'happiness'

01-31/0067c 肉 'meat'

23-25/0221a 飛 'fly'

11-05/1214a 屈 'bend'

10-08/0115a 申 'stretch'

24 Schuessler reconstructs *g-lay, a view that relies on combining GSR 0700 with GSR 0746, a velar initial series. Baxter \& Sagart $(2014 \mathrm{~b})$ reconstruct $*\left[\mathrm{~N}-\mathrm{r}^{\mathrm{s}} \mathrm{a}\right.$. The most neutral (late) Old Chinese reconstruction is * $1^{\mathrm{s}} \mathrm{a}$, and we employ this reconstruction here.

25 Baxter \& Sagart (2014b) reconstruct *C. $]^{\mathrm{S} a[t]-s .}$

26 Baxter \& Sagart (2014b) reconstruct 邪 yae $<*$ [G](r)A, zjae $<$ *sə.GA, and zjo $<$ *sə.la.

27 I have switched these two characters around (see discussion at $8 \mathrm{~b}$ below). Coblin does not do this.

28 Without making his reasons explicit, Beckwith reconstructs with a final *-r (2008: 97).

29 Without making his reasons explicit, Beckwith reconstructs with a final *-r (2008: 97). The 

c. 仍 nəy $>$ ńin $>$ nying
04-38/0945e 悉 'all'
d. 離 rai $>$ liæi $>$ lje
18-11/0023f 備 'provided, furnished, prepared'
rais $>$ liæi $^{\mathrm{c}}>\mathrm{ljeH}$

11. a. 僂 $\mathrm{ro} ?>\mathrm{lio}^{\mathrm{b}}>\mathrm{ljuX}$

rio $>$ lo $>$ luw

b. 讓 nays $>$ ńaj $^{c}>$ nyangH

03-42/0730i 夷 'barbarians'

c. 龍 roy $>$ lion $>$ ljowng

12-15/1193a 貧 'poor'

$\mathrm{mr}^{\mathrm{S}}$ oy $>$ mon $>$ maewng

d. 洞 $\mathrm{d}^{\mathrm{s}}$ ons $>\mathrm{don}^{\mathrm{c}}>$ duwngH

12-09/1176h 薄 'thin (= poor)'

12. a. 莫 $\mathrm{mr}^{\mathrm{s}} \mathrm{ak}>\mathrm{mæk}>$ maek

02-40/0802a 無 'have not'

$\mathrm{m}^{\mathrm{s} a k}>\mathrm{mak}>\mathrm{mak}$

$\mathrm{m}^{\mathrm{s}} \mathrm{aks}>\mathrm{ma}^{\mathrm{c}}>\mathrm{muH}$

b. 支 $\mathrm{ke}>\mathrm{kie}>\mathrm{t}$ śe $>$ tsye

07-03/0864a 所 relative clause nominalizer

c. 度 $\mathrm{d}^{\mathrm{I}} \mathrm{ak}>\mathrm{dak}>\mathrm{dak}$

02-16/0801a 報 'repay, give in repayment'

$\mathrm{d}^{\mathrm{S}}$ aks $>\mathrm{da}^{\mathrm{c}}>\mathrm{duH}$

d. 由 $\mathrm{lu}>\mathrm{jiou}>\mathrm{yuw}^{31}$

13-30/1079a 嗣

13. a. 陽 lay $>$ jay $>$ yang

b. 雒 $\mathrm{r}^{\mathrm{s} a k}>\mathrm{lak}>\mathrm{lak}$

c. 僧 sən $^{32}>$ song

03-38/0720e 願 'wish, desire'

d. 鱗 $\operatorname{rin}>$ lin $>$ lin

02-01/0766q 主 'ruler'

06-19/0884- 壽 'longevity'

32-26/0387k 長 'long'

14. a. 莫 $\mathrm{mr}^{\mathrm{s}} \mathrm{ak}>\mathrm{mæk}>$ maek

02-40/0802a 子 'son'

$\mathrm{m}^{\mathrm{s}} \mathrm{ak}>\mathrm{mak}>\mathrm{mak}$

$\mathrm{m}^{\mathrm{s}} \mathrm{aks}>\mathrm{ma}^{\mathrm{c}}>\mathrm{muH}$

b. 稚 $\mathrm{drih}>\mathrm{dij}^{\mathrm{c}}>\mathrm{drijH}$

28-11/0575y 孫 'grandson'

c. 角 $\mathrm{kr}^{\mathrm{c}} \mathrm{ok}>\mathrm{kok}>\mathrm{kaewk}$

11-02/1225a 昌 'splendid'

d. 存 $\mathrm{dz}^{\text {`ən }}>\mathrm{dzən}>\mathrm{dzwon}^{33}$

33-22/0432a 熾 'glorious'

reconstruction *[b]e[n] of Baxter \& Sagart (2014b) allows for a final *-r, but does not posit one.

30 Baxter \& Sagart (2014b) reconstruct 後 ${ }^{*} \mathrm{G}^{\mathrm{S}} \mathrm{O}$.

31 Schuessler in fact reconstructs Old Chinese 由 *ju (2009: 175); I follow Baxter \& Sagart (2014b) in rejecting initial $* \mathrm{j}$ - in Old Chinese.

32 Schuessler does not offer an Old Chinese reconstruction for the reading of this character.

33 Schuessler regards the rime development as irregular. 


\section{Poem 2}

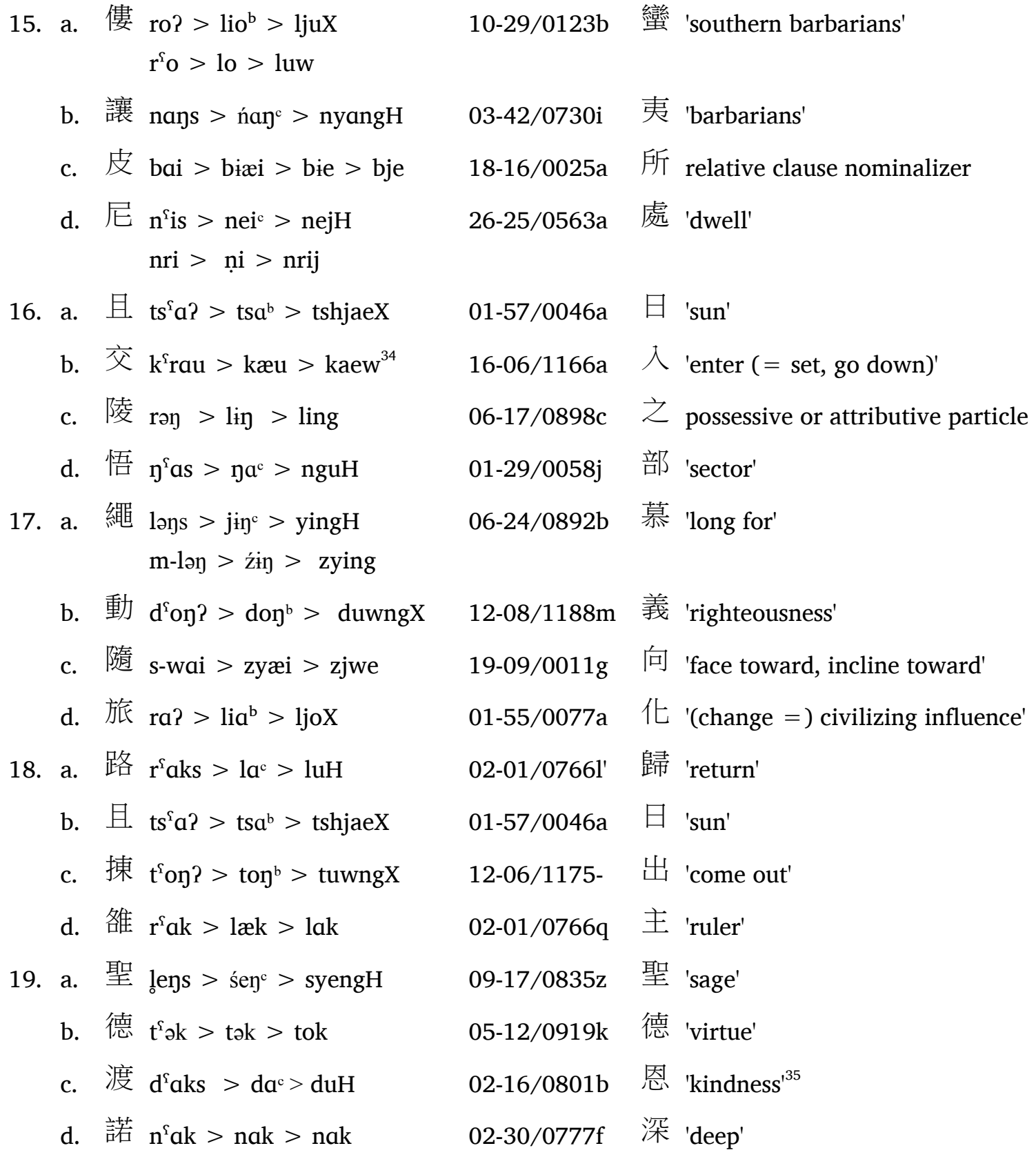

34 Schuessler's in fact reconstructs Old Chinese ${ }^{*} \mathrm{k}^{\mathrm{a}} \mathrm{au}$, with no medial $-\mathrm{r}-$, which is a surprise since the $-\mathrm{r}$ - is needed to explain the vocalism of his Han reconstruction. I follow Baxter \& Sagart (2014b) in reconstructing * $\mathrm{k}^{\mathrm{S}}$ raw.

35 This and the next character are reversed following the suggestion of Coblin (1979: 190). 
20. a. 魏 $\mathrm{y}^{\mathrm{w}} \curvearrowright \mathrm{i}(\mathrm{s})>\operatorname{nui}(\mathrm{c})>\operatorname{ngjwij}(\mathrm{H})$

b. 菌 gun? $>\operatorname{guin}^{\mathrm{b}}>\operatorname{gwinX}^{36}$

c. 度 $\mathrm{d}^{\mathrm{s}} \mathrm{ak}>\mathrm{dak}>\mathrm{dak}$ $\mathrm{d}^{\mathrm{s}} \mathrm{aks}>\mathrm{da}^{\mathrm{c}}>\mathrm{duH}$

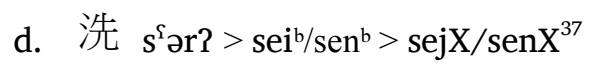

21. a. 綜 ts $^{\mathrm{s}}$ uns $>$ tsoun $^{\mathrm{c}}>$ tsowngH

b. 邪 ja $>$ jæ $>$ yae s-la $>$ ziæ $>$ zjae s-la $>$ zia $>$ zjo

c. 流 $\mathrm{ru}>$ liu $>$ ljuw

d. 藩 par $>$ puan $>$ pjon $^{38}$

22. a. 莋 $\mathrm{dz}^{\S} \mathrm{ak}>\mathrm{dzak}>\mathrm{dzak}$

b. 邪 ja $>$ jæ $>$ yae s-la $>$ ziæ $>$ zjae s-la $>$ zia $>$ zjo

c. 尋 $\mathrm{s}-\mathrm{l} ə \mathrm{~m}>\mathrm{zim}>\mathrm{zim}^{39}$

d. 螺 $\mathrm{r}^{\mathrm{S}} \mathrm{Oi}^{40}>$ luai $>$ lwa

23. a. 䔔 $\mathrm{mr}^{\mathrm{s}} \mathrm{wak}>\mathrm{mok}>$ maewk

b. 潯 s-ləm > zim > zim

c. 瀘 $\mathrm{r}^{\mathrm{s}} \mathrm{a}>\mathrm{la}>\mathrm{lu}$

d. 漓 $\mathrm{rai}>\mathrm{liæi}>\mathrm{lje}$

24. a. 菌 gun? $>\operatorname{guin}^{\mathrm{b}}>\operatorname{gwinX}^{41}$

b. 補 $\mathrm{p}^{\mathrm{q}} \mathrm{a}$ ? $>\mathrm{pa}^{\mathrm{b}}>\mathrm{puX}$

c. 邪 $\mathrm{ja}>\mathrm{jæ}>$ yae s-la $>$ ziæ $>$ zjae s-la $>$ zia $>$ zjo

d. 推 $\mathrm{t}^{\mathrm{h}} \mathrm{ui}>\mathrm{t}^{\mathrm{h}} \mathrm{uəi}>$ thwoj

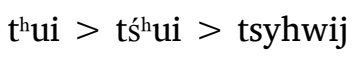

28-01/0569k 與 'together with'

34-11/0484c 人 'people, men'

02-16/0801a 富 'rich'

33-25/0478j 厚 '(thick =) affluent'

15-13/1003f 冬 'winter'

01-47/0047a 多 'much'

13-46/1104a 霜 'frost'

24-54/0195s 雪 'snow'

02-31/0806- 夏 'summer'

01-47/0047a 多 'much'

38-17/0662a 和 'harmonious'

28-15/0577- 雨 'rain'

16-42/1171c 寒 'cold'

38-17/0662- 溫 'warm'

01-51/0069- 時 'time, season'

18-11/0023- 適 'suitable, in balance'

34-11/0484c 部 'tribe'

01-67/0102c' 人 'person'

01-47/0047a 多 'much'

28-11/0575a' 有 'have'

36 Baxter \& Sagart (2014b) reconstruct *grun?; their reason for a medial -r- is unclear to me.

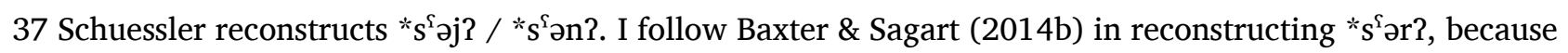
the series, and indeed this character, mixes readings with final $-\mathrm{n}$ and $-\mathrm{j}$ (cf. note 38 ).

38 Schuessler reconstructs *pan. I follow Baxter \& Sagart (2014b) in reconstructing *par, because the series mixes readings with final $-\mathrm{n}$ and final -j. Beckwith (2008: 104) claims that 洗 * $\mathrm{s}^{\mathrm{S}} \mathrm{r}$ ? and 藩 *par rhyme.

39 Baxter \& Sagart (2014b) do not reconstruct a reading for this character. In their system the 'pre-initial' *s- would have to be 'loose' in order for an OChi. lateral to change to MChi. z- (2014a: 191). 


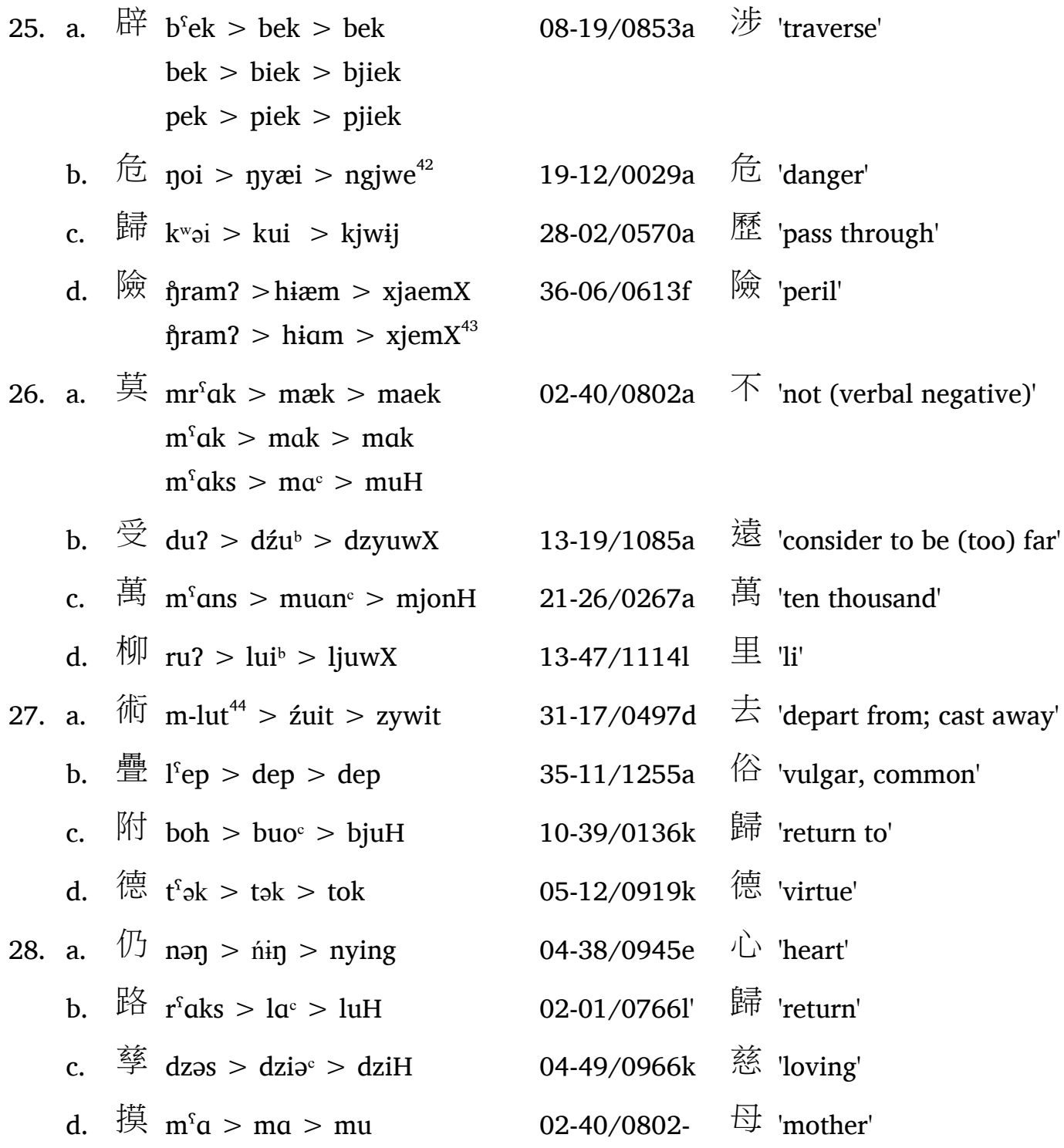

\section{Poem 3}

40 Baxter \& Sagart (2014b) reconstruct *k.r ${ }^{\mathrm{S}}$ oi.

41 Baxter \& Sagart (2014b) reconstruct "grun?; see note 36.

42 Baxter \& Sagart (2014b) reconstruct *[y](r)[o]i.

43 Baxter \& Sagart (2014b) reconstruct * $\mathrm{q}^{\mathrm{h}} \mathrm{r}[\mathrm{a}] \mathrm{m}$ ?; see note 19.

44 Baxter \& Sagart (2014b) reconstruct *Cə-lut. 
29. a. 荒 $m_{0}^{\mathrm{s}} a \mathrm{a}>$ huay $>$ xwang

b. 服 bək $>$ buk $>$ bjuwk bə? $>$ bu $^{\mathrm{b}}>$ bjuwX

c. 之 tə > tśə $>$ tśi $>$ tsyi

d. 儀 nai $>$ niæi $>$ ngje

30. a. 犁 $\mathrm{r}^{\mathrm{s}} \mathrm{i}>$ lei $>$ lej ri $>$ li $>$ lij

b. 籍 $\mathrm{dz}\left({ }^{\S}\right) \mathrm{ak}^{45}>$ dziak $>$ dzjek

c. 憐 $\mathrm{r}^{\text {s }}$ in $>$ len $>$ len

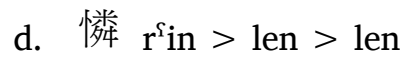

31. a. 阻 $\operatorname{tsra} 2>\mathrm{tṣ}^{\mathrm{b}}>\mathrm{tsrjoX}$

b. 蘇 $\mathrm{sy}^{\S} \mathrm{a}>\mathrm{sa}>\mathrm{su}$

c. 邪 ja $>$ jæ $>$ yae s-la $>$ ziæ $>$ zjae s-la $>$ zia $>$ zjo

d. 犁 $\mathrm{r}^{\mathrm{s}} \mathrm{i}>$ lei $>$ lej ri $>$ li $>$ lij

32. a. 莫 $\mathrm{mr}^{\mathrm{f}} \mathrm{ak}>\mathrm{mæk}>$ maek $\mathrm{m}^{\mathrm{s}} \mathrm{ak}>\mathrm{mak}>\mathrm{mak}$ $\mathrm{m}^{\mathrm{s}} \mathrm{aks}>\mathrm{ma}^{\mathrm{c}}>\mathrm{muH}$

b. 碭 $\mathrm{l}^{\mathrm{a}} \mathrm{ans}>\operatorname{danj}^{\mathrm{c}}>\mathrm{dangH}$

c. 粗 $\mathrm{ts}^{\mathrm{hs}} \mathrm{a}>\mathrm{ts}^{\mathrm{h}} \mathrm{a}>\mathrm{tsh} \mathrm{u}$

d. 沐 $\mathrm{m}^{\mathrm{s}} \mathrm{ok}>\mathrm{mok}>\mathrm{muwk}$

33. a. 罔 $\operatorname{man} 2>$ muan $^{\mathrm{b}}>\operatorname{mjangX}$

b. 驛 $\mathrm{lak}>\mathrm{jæk} \sim \mathrm{jak}>$ yek

c. 傳 dron $>$ dyæn $>$ drjwen $^{46}$

d. 微 məi $>$ mui $>$ mjij 03-65/0742e' 荒 'Huāngfù region'

05-35/0934d 服

04-27/0962a 之 Possessive or attributive particle

18-05/0002u 外 'outside'

26-24/0519g 土 'earth, soil'

02-32/0798a' 地 'earth'

32-26/03871 墝 'hard, stony'

$32-26 / 03871$ 埆

01-57/0046y 食 'eat'

01-31/0067c 肉 'meat'

01-47/0047a 衣 'wear'

26-24/0519g 皮 'skin'

02-40/0802a 不 'not (verbal negative)'

03-38/0720f' 見 'see'

01-57/0046h' 鹽 'salt'

11-24/1212e 穀 'grain'

03-65/07421 史 'official'

02-25/0790h 譯 'translator'

25-25/0231f 傳 'transmit'

27-18/0584d 風 '(wind =) news, accounts'

45 Baxter \& Sagart (2014b) reconstruct *[dz]Ak.

46 Because this word is a Chinese loan its meaning can be used to select among various Middle Chinese readings; the Middle Chinese reading is not drjwenH 'a record', or trjwenH 'relay post', but rather drjwen 'transmit'. 
34. a. 是 $\mathrm{de} 2>\mathrm{dź}^{\mathrm{b}}>\mathrm{dzyeX}$

b. 漢 hars $^{47}>$ han $^{\text {c }}>$ xanH

c. 夜 $\mathrm{jaks}^{48}>\mathrm{ja}^{\mathrm{c}}>\mathrm{yaeH}$

d. 拒 ga? $>$ gia $^{\mathrm{b}}>$ gjoX

$$
\mathrm{k}^{\mathrm{w}} \mathrm{a} ?>\mathrm{kya}^{\mathrm{b}}>\mathrm{kjuX}
$$

35. a. 蹤 tson $>$ tsion $>$ tsjowng

b. 優 $2 u>2 u>$ 'juw

c. 路 $\mathrm{r}^{\mathrm{s}} \mathrm{aks}>\mathrm{la}^{\mathrm{c}}>\mathrm{luH}$

d. 仁 $\operatorname{nin}>$ ńin $>$ nyin

36. a. 雷 $r^{\S} u i>l u ə i>l w o j$

b. 折 $d^{\mathrm{s} e}>\mathrm{de}>\mathrm{dejH}$

det $>$ dźat $>$ dzyet

tet $>$ tśat $>$ tsyet

c. 險 Đoram? $>$ hiæm $^{\text {b }}>$ xjaemX Đ̊ram? $>$ hiam $^{\text {b }}>$ xjemX $^{49}$

d. 龍 roy $>$ lion $>$ ljowng $\mathrm{mr}^{\mathrm{S}}$ oy $>$ moy $>$ maewng

37. a. 倫 run $>$ luin $>$ lwin

b. 狼 $\mathrm{r}^{\mathrm{s}}$ an $>$ lay $>$ lang

c. 藏 $\mathrm{dz}^{\S}$ ay $>$ dzay $>$ dzang $\mathrm{dz}^{\mathrm{s}} \mathrm{ayh}>\mathrm{dzay}^{\mathrm{c}}>\mathrm{dzangH}$

d. 幢 $\mathrm{dr}^{\mathrm{S}} \mathrm{O}$ ᄀ $>$ ḍjy $>$ draewng

38. a. 扶 ba $>$ bua $>$ bju

$$
\mathrm{p}^{\mathrm{h}} \mathrm{a}>\mathrm{p}^{\mathrm{h}} \mathrm{a}>\mathrm{phu}
$$$$
\text { pa }>\text { pua }>\text { pju }
$$
b. 路 $\mathrm{r}^{\mathrm{f}} \mathrm{aks}>\mathrm{la}^{\mathrm{c}}>\mathrm{luH}$
c. 側 tsrək $>$ tșịk $>$ tsrik
d. 祿 $\mathrm{r}^{\mathrm{f}} \mathrm{ok}>$ lok $>$ luwk

$\begin{array}{ll}07-14 / 0866 a & \text { 大 'great' } \\ 24-10 / 0144 c & \text { 漢 'Han' } \\ 02-27 / 0800 j & \text { 安 'peaceful' } \\ 01-19 / 0095 i & \text { 樂 'happy' }\end{array}$

12-22/1191- 攜 'take by the hand'

13-14/1071d 負 'carry on the back'

02-01/07661' 歸 'return'

32-28/0388f 仁 'humaneness'

28-15/0577o 觸 'encounter, but into'

21-19/0287a 冒 'risk, brave'

36-06/0613f 險 'precipitous'

12-15/1193a 陜 'gorge, chasm'

34-24/0470c Ш ${ }^{50}$ 'mountain'

03-43/07351 高 'high'

03-49/0727g' 岐 'precipitous'

12-08/1188e' 峻

01-66/0101f 緣 'follow along the edge'

02-01/0766l' 崖 'cliff, precipice'

05-24/0906c ! 'large stone' (?)

11-15/1208h 石 'stone'

47 The reconstruction combines Baxter \& Sagart's (2011) * $\mathrm{n}^{\mathrm{S}}$ ars and Schuessler's (2009) *h $\mathrm{h}^{\mathrm{S}}$ ans, because evidence suggests the need to treat *-r separately from * $n$ in the transcriptional Chinese dialect (cf. note 38), but the initial * $\mathrm{n}^{\mathrm{s}}$ - had almost certainly developed to *h- in the transcriptional dialect.

48 Baxter \& Sagart (2014b) reconstruct *N.rAk-s.

49 Baxter \& Sagart (2014b) reconstruct * $\mathrm{q}^{\mathrm{h}} \mathrm{r}[\mathrm{a}] \mathrm{m}$; ; see note 19.

50 This and the following character are reversed at Coblin's suggestion (1979: 194). 
39. a. 息 sək $>$ sik $>$ sik

b. 落 $\mathrm{r}^{\mathrm{s}} \mathrm{ak}>\mathrm{lak}>\mathrm{lak}$

c. 服 bək $>$ buk $>$ bjuwk bə? $>$ bu $>$ bjuwX

d. 淫 1 lom $>\mathrm{jim}>\mathrm{yim}$

40. a. 理 $\mathrm{r} 2>>\mathrm{li}^{\mathrm{b}}>\mathrm{liX}$

b. 曆 $\mathrm{r}^{\mathrm{s} e \mathrm{ek}}>\mathrm{lek}>\mathrm{lek}$

c. 髭 tse $>$ tsie $>$ tsje

d. 雒 $\mathrm{r}^{\mathrm{s}} \mathrm{ak}>\mathrm{lak}>\mathrm{lak}$

41. a. 捕 $b^{\varsigma} a s>b a^{c}>b u H$

b. 茞 gin $>$ gin $>$ dzyin

c. 菌 gun? $>\operatorname{guin}^{\mathrm{b}}>\operatorname{gwin}^{51}$

d. 毗 bi $>$ bi $>$ bjij

42. a. 懷 $\operatorname{gr}^{\varsigma} u j>$ guci $>$ hweaj

b. 稿 $\mathrm{k}^{\mathrm{s}} \mathrm{aw}$ ? $>\mathrm{kau}^{\mathrm{b}}>\mathrm{kawX}$

c. 匹 $\mathrm{p}^{\mathrm{h}}$ it $>\mathrm{p}^{\mathrm{h}}$ it $>$ phjit

d. 漏 $\mathrm{r}^{\mathrm{s}} \mathrm{OS}>1 \mathrm{lo}^{\mathrm{c}}>\mathrm{luwH}$

43. a. 傳 dron $>$ dyæn $>$ drjwen

b. 室 $\operatorname{lit}^{52}>$ śit $>$ syit

c. 呼 $h^{\S} \mathrm{a}>\mathrm{ha}>\mathrm{xu}$, $\mathrm{h}^{\mathrm{f}} \mathrm{as}>\mathrm{ha}^{\mathrm{c}}>\mathrm{xuH}$

d. 敕 rə $^{\prime}>t^{\mathrm{h}} \mathrm{ik}>$ trhik

44. a. 陵 rəy $>$ lin $>$ ling

b. 陽 lay $>$ jay $>$ yang

c. 臣 gin $>$ dźin $>$ dzyin

d. 僕 $b^{\text {ई }} \mathrm{Ok}>$ bok $>$ bowk, buwk 05-29/0925a木 'wood'

02-01/0766q' 薄 'thicket'

05-35/0934d 發 'send forth, bring forth'

38-15/0657b 家 'home, family'

04-35/0978d 百 'hundred'

08-13/0858h 宿 'overnight stay'

07-25/0358n 到 'reach, arrive at'

02-01/0766q 洛 'Lo-yang'

01-67/0102j'父 'father'

32-01/0377- 子 'son'

34-11/0484c 同 '(some, together =) altogether'

26-38/0566u 賜 'give'

28-06/0600c 懷 'cherish'

16-01/1129- 抱 'embrace'

29-38/0408a 匹 'roll'

10-27/0120a 帛 'silk'

25-25/0231f 傳 'transmit'

29-15/0413j 告 'tell'

01-17/0055h 種

'tribesmen'

05-15/0917a 人

06-17/0898c 長 'long'

03-38/0720e 願 'desire'

32-01/0377a 臣 'subject'

11-23/1211b 僕 'servant'

51 Baxter \& Sagart (2014b) reconstruct "grun?; see note 36.

52 Baxter \& Sagart (2014b) reconstruct *s.ti[t], a notation which permits final $-\mathrm{k}$, which would lead to a rhyme. 


\subsection{Etymological commentary}

The reconstructions of pre-historic forms of Tibetan and Burmese given in this commentary assume various proposal I have made in previous publications (see esp. Hill 2012).

1a. 堤 * $\mathrm{d}^{\mathrm{s}} \mathrm{e}>\mathrm{de}$ 大 'great' at 34a spelled 是 *de? $>$ dźe $^{\mathrm{b}}$. It is tempting to see this word as a loan from Chinese 大. However, if one assumes this loan relationship and accepts Baxter \& Sagart's (2014b) reconstruction 大 * $1^{5}$ ats (21-12/0317a), then the spellings 堤 and 是 would indicate that *1- had already changed to d- in type A syllables of the Chinese transcriptional dialect by the time of the poem's composition, whereas the comparison of 潭 *1`2m 'sweet' (8b) to Chi. 甜 dem < * $1^{\uparrow}$ em (36-16/0621-) 'sweet', etc. suggests that ${ }^{*} \mathrm{l}^{\mathrm{S}}$ - was retained as a lateral in the Chinese transcriptional dialect. There are two options to avoid this pitfall. First, one could understand 堤 * $\mathrm{d}^{\mathrm{s}} \mathrm{e} /$ 是 * de? 'great' to be an indigenous Bailang word. Beckwith takes this course, suggesting comparison with Tib. \$े č 'che 'be big' (2008: 107); one might also compare Bur. œữ tay 'very' (intensive) and Chi. 多 ta < *[t-1] ai (18-08/0003a) 'many'. Second, it is possible that this is a loanword, but that Schuessler's 大 * $\mathrm{d}^{\mathrm{f}}$ as is a better reconstruction of the Chinese source than Baxter \& Sagart's 大 *1'ats. On the development of laterals in the Chinese transcriptional dialect see the discussion at $39 d$.

1b. The word 官 " $\mathrm{k}^{\mathrm{wS}} \mathrm{an}>$ kuan 漢 'Chinese', spelled 漢 at 34b, is a clear loanword from Chinese 漢 ${ }^{*} \mathrm{n}^{\mathrm{s}} \mathrm{ars}>\mathrm{han}^{\mathrm{c}}$. The spelling of 漢 with 官 is intriguing for two reasons. First, there is a mismatch of initials (cf. note 47). Second, Chinese 漢 *ñ ${ }^{\mathrm{s}}$ ars has a final -r, and other evidence points to the need to distinguish *-r from *-n in the transcriptional dialect and Bailang (cf. note 38). Baxter \& Sagart (2014b) reconstruct 官 ${ }^{*} \mathrm{k}^{\mathrm{wS}} \mathrm{a}[\mathrm{n}]$, leaving open the possibility that this word has a final *-r. Beckwith (2008: 96) reconstructs 官 *kar.

1c. 隗 * $\mathrm{y}^{\mathrm{w}}$ əi > yui 是 'this, that'. Neither Schuessler (2009: 291) nor Baxter \& Sagart (2014b) provide reconstructions for this character. I reconstruct " $\mathrm{n}$ wəi $>$ yui in Schuessler's system. On the development of OChi. *-ə- in the Chinese transcriptional dialect see discussion at 13a.

1d. 構 " $\mathrm{k}^{\mathrm{s}} \mathrm{os}>\mathrm{ko}^{\mathrm{c}}$ 治 'to be in order, to put in order'

2a. 魏 * $y^{w}$ əi(s) > yui $\left({ }^{(}\right)$與 'together with'. Also occurs at 20a. On the development of OChi. *-ə- in the Chinese transcriptional dialect see discussion at 13a.

2b. 冒 “ $m^{\varsigma} u s>m^{c}$ 天 天 'Heaven'. OTib. 移' $d m u$ 'a type of sky god' (cf. Coblin 1987), 


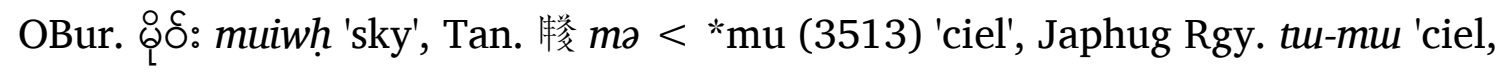
pluie', Rawang Dvmø 'spirits of the upper realm' (LaPolla \& Poa 2001: 13). The comparanda suggest the Bailang vowel was closer to the OChi. reading than the Han reading. Ma \& Dai (1982: 22) and Zhengzhang (1993: 14) also note the same Burmese cognate, the former also proposing related forms in other languages.

2c. 逾 *lo > jo 合 'unite, join'. Zhengzhang (1993: 14) understands 逾 *lo > jo 合 'unite, join' as meaning 意 'intention' and compares WBur. o lui 'to want' and Chi. 欲 yowk $<{ }^{*} \mathrm{G}(\mathrm{r}) \mathrm{ok}(11-14 / 1202 \mathrm{~d})$ 'to desire', which he reconstructs with initial *1-.

2d. 糟 *ts ${ }^{\mathrm{f}} \mathrm{u}>$ tsou 意 'intention'. Zhengzhang (1993: 14) understands 糟 *t ${ }^{\mathrm{f}} \mathrm{u}>$ tsou as meaning 合 'unite, join' and compares Bur. @ cu 'gather' and Chi. 遭 $t s a w<{ }^{*} \operatorname{ts}^{\mathrm{s}} \mathrm{u}$ (1355/1053h) 'encounter'.

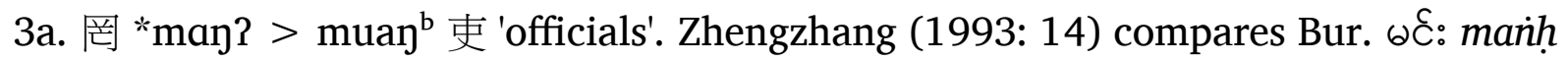
'king'. This word also occurs at 33a.

3b. 驛 *lak > jæk jak 譯 'translator'. Also occurs at 33b.

3c. 劉 *ru > liu 平 'just, fair'. Zhengzhang (1993: 14) compares WBur. ด̊: ruih 'honest, naïve, simple'.

3d. 脾 *be $>$ bie 端 'honest'.

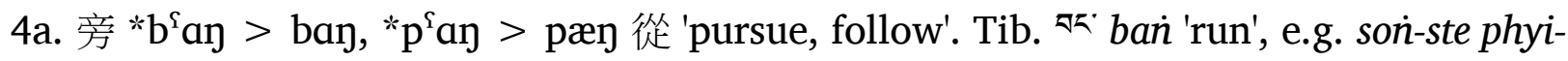
rol-tu ban்-nas / brag mthon-po źig-la mchons-so / 'he went, ran away, and jumped from a high precipice' (Mdz. 146a-b); bla-ma-la grwa-pa rta-bas ban mgyog-pa/ glan-po-chebas che-ba gcig yod-pa...the lama had a monk who was faster than a horse and stronger than an elephant' (Mila, de Jong 1959: 40).

4b. 莫 *mr ${ }^{\mathrm{f}} \mathrm{ak}>\mathrm{mæk},{ }^{*} \mathrm{~m}^{\mathrm{f}} \mathrm{ak}>\mathrm{mak},{ }^{*} \mathrm{~m}^{\mathrm{f}} \mathrm{aks}>\mathrm{ma}^{\mathrm{c}}$, 不 'not'. Chi. 無 $m j u<{ }^{*} \mathrm{ma}(01-$ 69/0103a) 'not have', Tib. ${ }^{\text {J' }} m a$ 'not', Bur. 6 ma 'not', etc. (see Coblin 1979: 200, Ma \& Dai 1982: 21, Zhengzhang 1993: 14). The word also occurs with this spelling and meaning at $12 \mathrm{a}, 26 \mathrm{a}$, and $32 \mathrm{a}$. One must assume the reading ${ }^{*} \mathrm{~m}^{\mathrm{s}} \mathrm{aks}>\mathrm{ma}^{\mathrm{c}}$ rather than ${ }^{*} m r^{\mathrm{S}} \mathrm{ak}>\mathrm{mæk}$ is intended and that *-ks had reduced to $-\mathrm{h}$ (or tone ${ }^{\mathrm{c}}$ ), i.e. Baxter's 'final cluster simplification' (1992: 568). Baxter points to the rhyme of 路 luH $<$ *Cə.r'ak-s 'road' (02-01/0766l') and 柘 tsyaeH < *tAk-s a 'kind of mulberry tree'

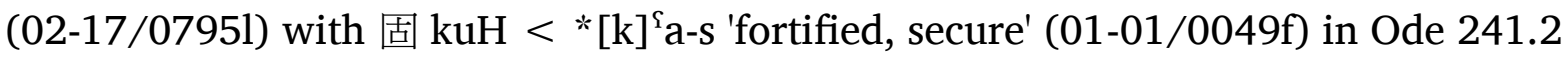
as evidence of the early date of this change (1992: 568). In addition, in early Han dynasty renderings of foreign words Old Chinese *-ks never reflects foreign -s but instead "the rare transcriptions suggest an $-h$ or $-\chi$ " (Schuessler 2009: 23). A piece of evidence, specific to the reading of 莫 is the transcription 莫邪 for the name of the 
Buddha's mother, reflecting either Māyā or Mah[ā-Mā]yā. ${ }^{53}$ This transcription appears in a narrative from the Wei lüe 魏略, a lost historical work compiled in ca. $265 \mathrm{CE}$; the Wei lüe quotation is included in a 5th-century commentary to another late 3rd-century history, the 三國志 Sanguo zhi (vol. 30, pp. 859-60). However, the Wei lüe links the story to information that would have been conveyed to the Han court by foreign (Yuezhi) envoys in 2 BCE. If so, the transcription is likely to reflect the phonology of the late 1 st century BCE rather than that of the 3rd century CE. ${ }^{54}$

It is something of a surprise that this negation word appears not to precede a verb at $4 \mathrm{~b}$ and $12 \mathrm{a}$. The same character, potentially with a different reading, writes the word 'son' at $14 \mathrm{a}$.

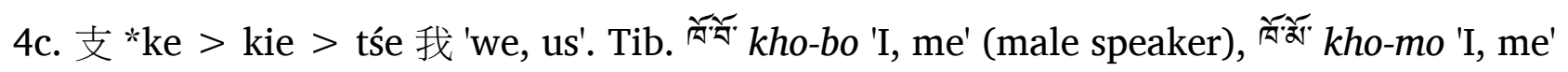
(female speaker), Olekha kö 'I', Hakka Lai ka- 'my', Hayu gu 'I, me', Chang kr-, Táopíng Qiang $q o^{55}$ 'my', $q a^{55}$ 'me', Puxi $q a$ 'me' (cf. Jacques 2007). It is noteworthy that, so far as we know, no trace of a velar or uvular initial first person pronoun is preserved in a Lolo-Burmese language. The loss of such a pronoun is thus an innovation of these languages relative to Bailang, which they are often considered closely related to (e.g. Coblin 1979: 198, 204 and Beckwith 2008: 95). Coblin points out that 莫支 at 12ab also occurs at 12ab, where the combination is glossed 無所 rather than 不我 (1979: 186). He consequently suggests that the gloss 我 'we, us' may be mistaken. However, bearing in mind that he translates 無所 as "we have not that which we (give in repayment)" (1979: 186), it is not at all unlikely that 支 here too marks a first person plural subject. Coblin further notes that "a variant form of this same word is almost certainly represented by 6a 知 triiei which also corresponds to 支” (1979: 186). Nonetheless, the phonological difference between 支*ke $>$ kie $>$ tśe and 知 *tre $>$ tie makes it unlikely that they reflect the same morpheme. If 支 is indeed a subordinate marker it is perhaps cognate to the Japhug Rgy. subject participle ku(Jacques 2016) and related velar nominalization prefixes in other languages (Konnerth 2016). One might fear that the comparisons of 支 *ke $>$ kie $>$ tśe 我 (4c) 'we, us' with cognates that have velar initials may not be appropriate because Chinese palatalized velars before front vowels early in the Hàn dynasty (Baxter \& Sagart 2014a: 79). However, Miyake shows that in the 魏志 Wei zhi of 陳壽 Chen Shou (233-

53 Pulleyblank (1983: 79) mentions this transcription, but makes little use of it.

54 The one piece against final cluster simplification in the transcriptional dialect is the comparison of Bailang 路 * $\mathrm{r}^{\mathrm{S}} \mathrm{aks}>1 \mathrm{la}^{\mathrm{c}}$ 崖 'cliff, precipice' (38b) to Tib. 퀘' brag 'cliff', but it seems possible that this character also had a rusheng reading (vide infra). 
297 CE) the character 支 is used to transcribe Japonic velar initials (2003: 111-113). If so, there is no problem proposing that velars were unpalatalized in the earlier Bailang songs.

4d. 留 *ru > liu 來 'cause to come'. Coblin compares Bur. os lā 'come' (1979: 209 note 46), a comparison Ma \& Dai repeat (1982: 22). The correspondence of the vowels is a problem; I prefer to compare the same Burmese word to 路 * $\mathrm{r}^{\mathrm{f}} \mathrm{aks}>1 \mathrm{a}^{\mathrm{c}}$ 歸 'return' (18a) (see discussion at 4b and 11a-b). It is of course possible that 留 *ru > liu 來 'cause to come' (4d) and 路 * $\mathrm{r}^{\mathrm{f}} \mathrm{aks}>\mathrm{la}^{\mathrm{c}}$ 歸 'return' (18a) are morphologically related words in Bailang.

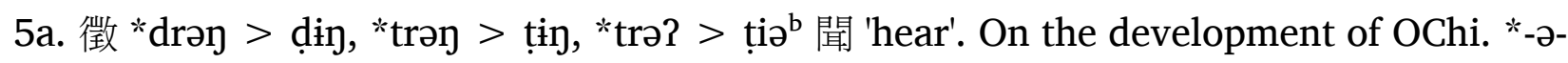
in the Chinese transcriptional dialect see discussion at 13a.

5b. 衣 *Pəi(s) > Pii( $\left(^{c}\right)$ 風 '(wind =) custom'. Coblin compares WBur 600 le < OBur *liy 'wind' (1979: 211: 111, also cf. Tan. 狶 lji < *lji [2302], Japhug Rgy. qale). This suggestion is only plausible if one supposes that 衣 'jij < ${ }^{*} ?(r) ə j$ (27-05/0550a) 'clothes' had the medial *-r- which Baxter \& Sagart (2014b) permit for it, but do not endorse. Even then, the vowel correspondence is not convincing. Zhengzhang (1993: 14) compares WBur. development of OChi. *-ə- in the Chinese transcriptional dialect see discussion at 13a.

5c. 隨 “s-wai > zyæi 向 'face toward'. The phrase 隨旅 s-wai ra? > zyæi lia' 'face toward the civilizing influence' also occurs at $17 \mathrm{c}-\mathrm{d}$.

5d. 旅 *ra? > lia ${ }^{\mathrm{b}}$ 化 '(change $=$ ) civilizing influence'. Coblin plausibly compares 旅 *ra? $>$ lia $^{\mathrm{b}}$ 化 'change' with Bur. ò lai 'change v.' (1979: 209 note 42). Also compare Tib. 宅 rje < *rl'e 'exchange' (Hill 2013: 203), Tan. 閑 lej < *lej (5834) 'changer, se transformer' (Jacques 2014: 175), and OChi. 易 yek < *lek 'change, exchange' (0812/0850a). The phrase 隨旅 s-wai ra? > zyæi lia ${ }^{\mathrm{b}}$ 'face toward the civilizing influence' also occurs at $17 \mathrm{c}-\mathrm{d}$.

6a. 知 *tre $>$ ție 所 relative clause nominalizer. See discussion at 4c.

6b. 唐 * $1^{\mathrm{I}}$ ay (cf. note 24) > day 見 'see'. Coblin (1979: 200), Ma \& Dai (1982: 21-22), and

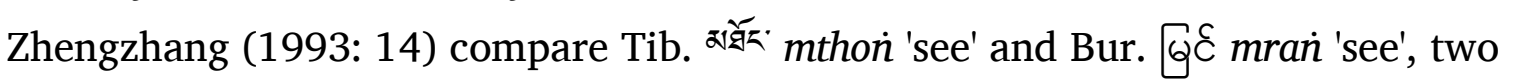
words that Nishida previously proposed as cognates (1957: 54-55, 1977: 5).

Zhengzhang (1993: 14) further compares OChi. 望 mjangH < *man-s (03-65/0742m) 'look at from a distance'. The comparison with Burmese appears exceptionally strong if one compares Baxter \& Sagart's (2011) reconstruction *[N-] $\mathrm{r}^{\S}$ ay. However, this word also occurs at $32 \mathrm{~b}$ spelled 碭 * $1^{\mathrm{s}} \mathrm{a}$ h $>\mathrm{da \eta}^{\mathrm{c}}$ 見 'see'. The comparison of Bailang 潭 *1 $1^{\text {`əm }}>$ dəm 甘 'sweet' (8b) with Trans-Himalayan cognates beginning with 1-, 
suggests that the transcriptional Chinese dialect * $1^{\text {s }}$ - had not yet changed to d-, but the transcription of the Bailang word for 'see' as both 唐 *[N-] $\mathrm{r}^{\mathrm{s}}$ ay $>$ day and 碭 * $\mathrm{l}^{\mathrm{f}}$ ayh $>\operatorname{day}^{c}$ suggests that the transcriptional Chinese dialect had already merged $*[\mathrm{~N}-] \mathrm{r}^{\mathrm{S}}$ with *1 ${ }^{\mathrm{s}}$ -

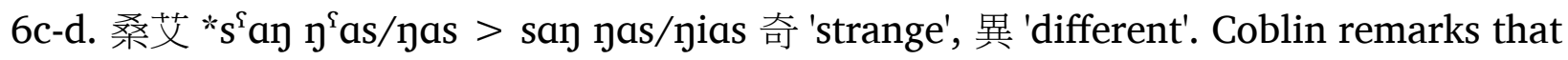
the “Chinese expression 奇異 'strange, extraordinary' is a synonym compound, and it is possible that 6c-d [桑艾] sang ngàd is also a compound. The fact that bisyllabic compounds do in fact occur in the Pai-lang text is indicated by 30c-d [粼憐] lian-lian 'hard, stony'" (1979: 187).

7a. 邪 *ja > jæ, *s-la > ziæ, *s-la > zia 多 'much, manifoldly. Ma \& Dai (1982: 21-22) propose a number of possible cognates, the most promising of which is Pumi 3 . This word also occurs at 21b, 22b, and 24c.

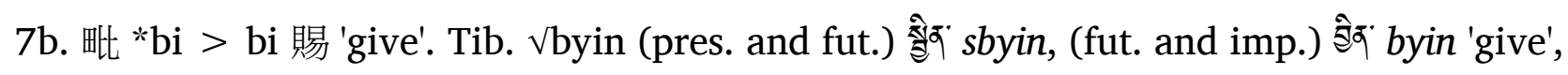
OBur. ¿ơ: piyḥ (cf. Ma \& Dai 1982: 22). Zhengzhang (1993: 15) further compares Chi. 界 pjijH < *pi[t]-s (29-39/0521a) 'give', a reasonable suggestion despite the irregularity of the correspondence. This word also occurs at 41d.

7c. 課 * $\mathrm{k}^{\mathrm{h}} \mathrm{Ois}>\mathrm{khuaic}$ 繒 'silk'.

7d. 諸 *ta > tśæ 布 'cloth'.

8a. 推 * ${ }^{\mathrm{hs}} \mathrm{ui}>\mathrm{t}^{\mathrm{h}} \mathrm{uəi}$, * $\mathrm{t}^{\mathrm{h}} \mathrm{ui}>\mathrm{ts}^{\mathrm{h}} \mathrm{ui}$ 美 'beautiful, fine'. In the transcriptional Chinese dialect -ui had already broken to -uəi (cf. note 21). Coblin identifies this word with the gloss Chi. 甘 'sweet' and compares with Jinghpaw daw $d w i\left(d u i^{31}\right.$ in $\mathrm{Xu}$ et al. 1983) and Mizo tui (1979: 210 note 87); Ma \& Dai add further comparisons including Pumi thu ${ }^{13}$ (1982: 22). However, I find the etymological comparison of Bailang 潭 ${ }^{*} 1^{\mathrm{S}}$ əm $>$ dəm with Trans-Himalayan words meaning 'sweet' sufficiently compelling to instead warrant the equation of Bailang 潭 *1 ${ }^{1}$ m $>$ dəm with Chinese gloss 甘 'sweet' and identify 推 with the Chinese gloss 美 'beautiful'. Zhengzhang (1993: 15) compares Bur. $\infty_{\mathbb{L}}$ : thuh 'extraordinary, special'. See discussion at $8 \mathrm{~b}$.

8b. 潭 *1'əm > dəm 甘'sweet', Chi. 甜 dem < *1'em (36-16/0621-) 'sweet', Tib. बे邓' żim < *jijm 'tasty', Tan. 不 lizij < *lim [1079] 'bon à manger', Th. rem rim 'beer drunk during the death ritual'. This word provides evidence that ${ }^{\text {s }} \mathrm{l}^{\text {- }}$ had not yet changed to d- in the transcriptional Chinese dialect (but also cf. remarks at 1a). On the development of OChi. *-ว- in the Chinese transcriptional dialect see discussion at 13a. 8c. 僕 * $\mathrm{b}^{\mathrm{s}}$ ok $>$ bok, ${ }^{*} \mathrm{p}^{\mathrm{hs}}$ ok $>\mathrm{p}^{\mathrm{h}}$ ok 酒 'wine'. Compare Khaling bhukt 'ferment' (Jacques 2015: 85 table 5).

8d. 遠 *wans $>$ wan $^{\mathrm{c}}$, *wan? $>$ wan ${ }^{\mathrm{b}}$ 食 'food'. The apparent rhymes with 便 *ben $>$ 
biæn 飛 'fly' (9d) and 存 “ $d z^{\text {` }}$ ən $>$ dzən 熾 'glorious' (14d), for which the cognates suggest a final -r, points to the possibility that this word also has a final -r. Beckwith reconstructs 遠 *war (2008: 97). Zhengzhang (1993: 15) compares Bur. uć: harḥ 'curry'.

9a. 拓 * $\mathrm{t}^{\mathrm{hS}} \mathrm{ak}>\mathrm{t}^{\mathrm{h}} \mathrm{ak}$ 昌 'splendid, bright'.

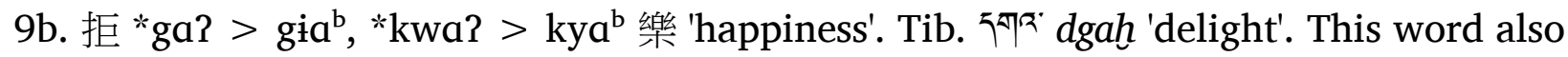
occurs at $34 \mathrm{~d}$.

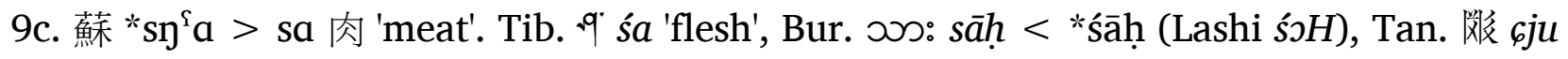
(2385) 'viande, chair' (Jacques 2014: 75-76), Mizo. sâ < *śaa 'meat' (Chinbok hla) (cf. Hill 2014: 17-18). Zhengzhang (1993: 64) further compares OChi. 腊 sjek (0232/0798g) 'dried meat', a word missing in Baxter \& Sagart 2014b, which Schuessler 2009 reconstructs ${ }^{*} \mathrm{~s}\left({ }^{\S}\right)$ ak. Ma \& Dai also offer additional potential cognates (1982: 23). Whether Bailang merges *ś- and *s-, like Burmese, or whether the distinction is simply not captured in the Chinese transcription, is difficult to know. This case shows that the cluster *sy- had simplified to s- before the time of the transcriptional dialect. It may seem reasonable to assume that other s- prefixes likewise were fused by this time. However, the comparison of Bailang 潯 *s-ləm > zim 溫 'warm' (23b) with Bur. ơ lum 'warm' etc. show that *s- clusters before laterals were still distinct in the Chinese transcriptional dialect. Thus, *s- clusters in the transcriptional dialect are best handled on a case by case basis. This word 蘇 * $\mathrm{sy}^{\mathrm{I}} \mathrm{a}>\mathrm{sa}$ 肉 'meat' also occurs at 31b. 9d. 便 *bens $>$ biæn $^{\mathrm{c}}$, *ben $>$ biæn, *ben? > biæn ${ }^{\mathrm{b}}$ 飛'fly'. Compare Chi. 飛 *Cə.pər (27-

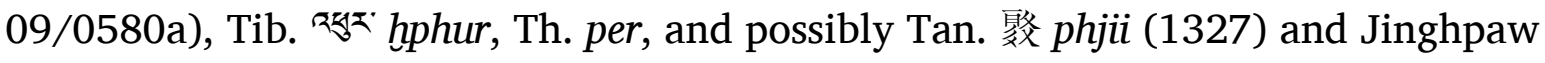
pjẹn $^{33}$ (Ma \& Dai 1982: 23, Xu et al. 1983). The reconstruction 便 *[b]e[n] of Baxter \& Sagart (2014b) allows for the possibility of a final *-r; Beckwith reconstructs the Bailang word as *bjar (2008: 97).

10a. 局 *gok > guok 屈 'bend'. Chi. 曲 khjowk < *kh(r)ok (11-04/1213a) 'bent, crooked',

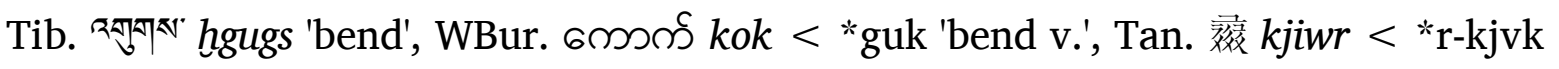
(1377) 'mauvais, penché', Japhug Rgy. kry 'courber' (cf. Zhengzhang 1993: 15).

10b. 後 * $\mathrm{h}^{\mathrm{f}} \mathrm{OS}>\mathrm{\gamma o}^{\mathrm{c}},{ }^{*} \mathrm{~h}^{\mathrm{f}} \mathrm{O}$ ? $>\mathrm{\gamma o}^{\mathrm{b}}$ 申 'stretch'.

10c. 仍 *nəy > ńin 悉 'all'. On the development of OChi. *-ə- in the Chinese transcriptional dialect see discussion at 13a.

10d. 離 *rai > liæi, *raih > liæic 備 'provided, furnished, prepared'. Coblin suggests that this may be the same word as 漓 *rai > liæi 適 'suitable, in balance' at 23d (1979: 188). Zhengzhang (1993: 15) proposes that this word is cognate with those words given here under $5 \mathrm{~d}$. 
11a-b. 僂讓 *ro? $/ \mathrm{r}^{\mathrm{s}}$ o nays $>$ lio $/$ lo ńajc 蠻 'southern barbarian', 夷 'barbarians'. Also occurs at 15a-b. Since the "Chinese term 蠻夷 'barbarians' is a binome” the corresponding Bailang syllables 僂讓 “probably also forms a compound" (Coblin 1979: 188). Coblin further speculates that this term may have been the Bailang autonym (1979: 188). I am instead tempted to compare Bailang 僂 * $\mathrm{ro} / \mathrm{r}^{\mathrm{s}} \mathrm{o}>1 \mathrm{lo} / \mathrm{lo}$ with Tib. 今̀ has already changed ${ }^{*} \mathrm{r}\left({ }^{\S}\right)$ - to 1-. Since 僂 has both type A and type B readings this hypothesis itself consists of two sub-hypotheses: 1 . ${ }^{*} \mathrm{r}^{\mathrm{S}}->$ 1- in type B syllables has already occurred, 2. *r- > 1- in type B syllables had already occurred.

Let us first consider the hypothesis anent type A syllables. There are two comparisons weighing in favor of ${ }^{*} \mathrm{r}^{\mathrm{S}}->1$ - in the transcriptional dialect:

1. 犁 * $\mathrm{r}^{\mathrm{S}} \mathrm{i}>$ lei, *ri > li 土 'earth, soil' (30a): Chi. 地 * $\mathrm{l}^{\mathrm{S}} \mathrm{ej}-\mathrm{s}$, etc.

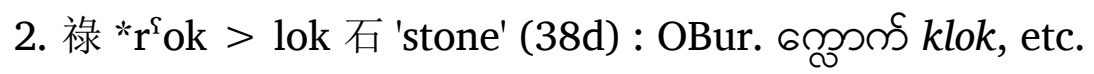

There are six comparisons weighing against ${ }^{*} \mathrm{r}^{\mathrm{S}}->1-$ :

1. 螺 ${ }^{\circ} \mathrm{r}^{\mathrm{o}} \mathrm{oi}>$ luai 雨 'rain' (22d) : Bur. ø $r w \bar{a}$, etc.

2. 瀘 “ $\mathrm{r}^{\mathrm{f}} \mathrm{a}>$ la 時 'time, season' (23c) : Tib. ^̀' re 'time' (Fr. fois)

3. 犁 * $\mathrm{r}^{\mathrm{s}} \mathrm{i}>$ lei, *ri > li 'skin' (31d), WBur. зə6९ a-re < OBur. *a-riy, etc.

4. 狼 *ray > lay 高 'high' (37b), Bur. 6등 mrañ?

5. 路 *r ${ }^{\mathrm{S}} \mathrm{aks}>\mathrm{la}^{\mathrm{c}}$ 崖 'cliff, precipice' (38b), Tib. 죆' brag 'cliff'

6. 曆 *rek > lek 宿 'overnight stay' (40b), OBur. Øюर ryak 'day', etc.

In addition, one must further note that ${ }^{*} \mathrm{r}^{\varsigma}>1$ - would have led to a merger with inherited $* 1^{\mathrm{s}}$-, as the strong comparison of 潭 * $1^{\mathrm{S}}$ วm $>$ dəm 甘 'sweet' (8b) to Chi. 甜 $* 1^{\text {s }}$ em 'sweet', etc. shows that the transcriptional dialect had not yet changed $* 1^{\text {s }}$ - to d-. On balance it seems more likely that ${ }^{*} \mathrm{r}$ > $>1$ - in type A syllables had not yet occurred in the transcriptional dialect.

Now let us turn to the second hypothesis. There are three comparisons weighing in favor of * $\mathrm{r}->1$ - in the transcriptional dialect in type B syllables:

1. 旅 *ra? > lia ${ }^{\mathrm{b}}$ 化 'change' (5d): Bur. ò lai 'change v.' etc.

2. 陵 *ron > lin 之 (16c, for meaning see 16c) : Tib. औ्ञई glin 'continent, island, garden', etc.

3. 路 “ $\mathrm{r}^{\mathrm{f}} \mathrm{aks}>1 \mathrm{a}^{\mathrm{c}}$ 歸 'return' (18a). Bur. cos lā 'come' or Tib. 취' log 'return' There are three comparisons weighing against the change ${ }^{*} \mathrm{r}->1$ - in type B syllables: namely

1. 鱗 *rin > lin 長 'long' (13d) / 陵 *roy > lin 長 'long' (44a) : Tib. ₹̂F rin, etc. 


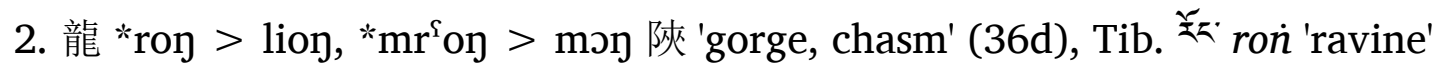

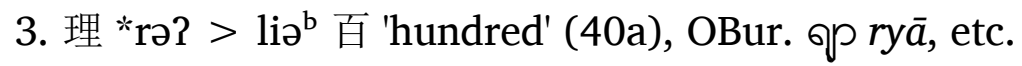

Although technically the evidence in favor of * $\mathrm{r}->$ 1- in type B syllables is equal to the evidence against, the evidence in favor has problems (such as the conjectural nature of the meaning of Bailang 陵 *rəy > lin 之 [16c]), whereas the evidence against is rather straightforward. Thus, again on balance it is more likely *r- was maintained as * $r$ - in the Chinese transcriptional dialect also in type B syllables.

Although in this discussion I give preference to those Trans-Himalayan cognates that point to * $r$ - in Bailang, by no means are the cognate proposals that point to *1-

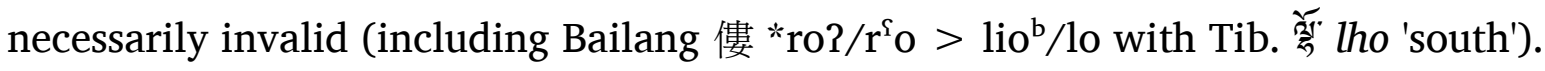
Within the Trans-Himalayan languages $\mathrm{r}: 1$ correspondences are disorderly, as

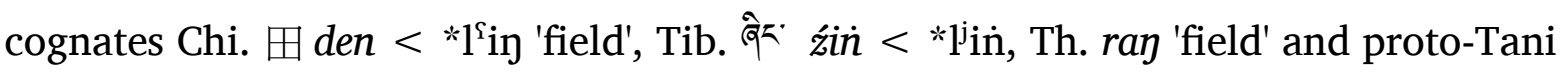
*ruk (Sun 1993: 180) ${ }^{55}$ (perhaps related to Bailang 陵 *ron > lin 之 [16c]) and Bur. cos lā 'come', Th. rah 'come' (perhaps related to Bailang 留 *ru > liu 來 'cause to come' [4d]). Only further research on the historical phonology of many languages will make the picture clearer.

Zhengzhang (1993: 15) compares 僂 * ${ }^{\circ} \mathrm{r} / \mathrm{r}^{\mathrm{s}} \mathrm{o}>\mathrm{lio}$ / $/ \mathrm{lo}$ 蠻 'southern barbarian' with Bur. o $\overbrace{\mathbb{L}} l \bar{u}$ 'person'.

One may reasonably wonder whether 讓 *nays $>$ ńaj $^{\mathrm{c}}$ 夷 'barbarians' is related to the Tibetan word ${ }^{2 E 5}$ hy̆an [ndzan], referring in Old Tibetan to the Nanzhao kingdom.

11c. 龍 *roy > lioy, *mrºy > moy 貧 'poor'. See discussion at 11d.

11d. 洞 * $\mathrm{d}^{\mathrm{S}}$ ons $>\operatorname{dog}^{\mathrm{c}}$ 薄 'thin (= poor)'. Coblin notes that since Chinese 貧薄 is a binome 'poor', Bailang 龍洞 may also be a binome.

12a. 莫 * $m r^{i} a k>m æ k, ~ * m^{i} a k>m a k,{ }^{*} m^{i} a k s>m a^{c}$ 無 'have not'. See discussion at $4 b$.

12b. 支 *ke $>$ kie $>$ tśe 所 relative clause nominalizer. See discussion at 4c.

$12 \mathrm{c}-\mathrm{d}$. 度由 * $\mathrm{d}^{\mathrm{s}} \mathrm{ak} / \mathrm{d}^{\mathrm{s}} \mathrm{aks} \mathrm{lu}>\mathrm{dak} / \mathrm{da}^{\mathrm{c}}$ jiəu 報嗣 'repay, give in repayment'. Since the Chinese is a binome, the Bailang is also likely a binome (Coblin 1979: 188). Zhengzhang (1993: 15) compares the first word with OChi. 度 dak $<*[d]^{\text {`ak }}(02-$ 16/0801a) 'measure (v.)', a good phonetic match but not compelling semantically. As a cognate to the second word Coblin points to WBur. 6ø: rweh < OBur. *ruyh 'choose, select, redeem, ransom' (1979: 202). I am inclined to reject this comparison

55 Sun supports proto-Tani *ruk 'swidden' with Bengni S ruk-pe:, Bokar OY a-ruk, and Padam-Mising L $a$ rik (1993: 221). 
for several reasons. First, the Burmese word has quite wide semantics. Until philological study confirms that 'redeem' and 'ransom' are more conservative meanings, the semantics are not persuasive. Second, Burmese has initial $r$ - in this word whereas Bailang has initial 1- (or j-). The more secure comparisons to 淫 *ləm > jim 家 'home, family' (see discussion at 39d) suggest that *1- in type B syllables had already changed to $\mathrm{j}$ - by the time of the transcriptional Chinese dialect. Nonetheless, it is possible that the change $* 1>\mathrm{j}$ - proceeded through several conditioned subchanges, in which case it might be possible that in the transcriptional Chinese dialect 淫 has initial j- but 由 still retained initial 1-. If one assumes that 由 did maintain initial 1-, then Zhengzhang's (1993: 15) comparison with Bur. @्ञ|l lhū 'donate, give' or Tib. 정 blu 'to ransom' are more promising than WBur. 6ด: rweh.

13a. 陽 *lan > jay 願 'wish, desire'. This word also occurs at 44b. Coblin suggests that it may be cognate with 繩 *lə⿹s $>\mathrm{jin}^{\mathrm{c}}$, *m-ləy $>$ źin 慕 'long for' at 17a (1979: 189), a proposal which raises the question of whether Bailang distinguishes -a- and -ə-. Two types of evidence bear on this question: 1 . distinct readings of what are perhaps the self-same Bailang word, 2. Trans-Himalayan cognates of Bailang words that are transcribed with Characters that have OChi. *-ə- readings. The case at hand, viz. 繩 *ləns > jin', *m-ləy > źin 慕 'long for' (17a) 陽 *lay > jan 願 'wish, desire' (13a, $14 \mathrm{~b}$ ) is the only instance of the former. In contrast, there are many examples of the latter, so many that it is helpful to organize them according to the final consonant implied by the proposed cognates.

Open syllables: There are three words transcribed as open syllables.

1. 衣 *2ai(s) > 2iii(c) 風 '(wind =) custom' (5b). WBur 600 le < OBur *liy 'wind', Tan. 疑 lji < *lji [2302], Japhug Rgy. qale). The cognates point to *-i-.

2. 玄 *dzəs > dziəc 慈 'loving' (28c). Chi. 慈 $d z i<$ *dzə (04-49/0966j) 'kind adj.',

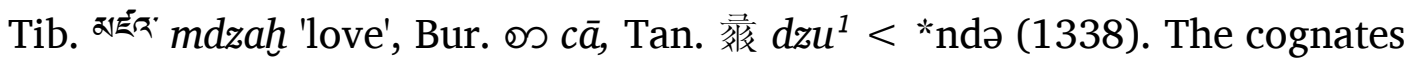
point to -ə-.

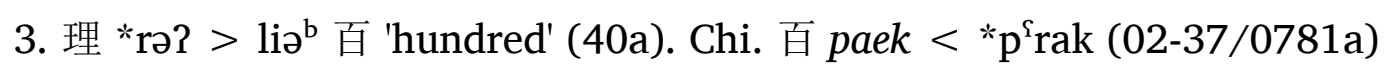

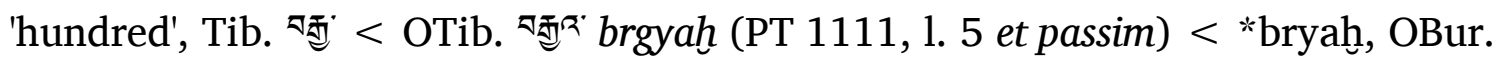

จ ryā, Tan. 娐 .jir ${ }^{2}<*$ *ja (2798), Japhug Rgy. yurza <*wə-rja (Jacques 2014:

92). The cognates point to *-a-.

The cognates point to a different vowel in each of the three word. Taking the Han vowels as a point of departure, it is plausible that Bailang -ii- is cognate with -i- in other languages whereas Bailang -iə- is cognate with -ə- or -a-.

In the word 'love' the transcriptional vowel -ə- matches the Chinese and pre- 
Tangut cognates exactly, suggesting Bailang maintained a distinction between -ə- and -a- in open syllables. If so, Bailang provides further evidence that Handel (2008) is incorrect in proposing the merger of -ə- and -a- in all languages other than Chinese.

Nonetheless, in 'hundred' both Chinese and pre-Tangut have -a-, distinct from the -ə- of Bailang. The two phonetic contexts are however not strickly speaking parallel because 'love' is qusheng, probably realized as -h in the transcriptional dialect, and 'hundred' is shangsheng, probably realized as 2 in the transcriptional dialect. In addition, the possibility should be considered that the Bailang word for 'hundred' is not cognate with Chi. 百 paek $<{ }^{*} \mathrm{p}^{\text {\& }}$ rak, Japhug Rgy. zurza etc. but instead with the bound Japhug Rgy. classifier -ri 'one hundred' and its cognates such as Pumi - $\lfloor$ jj (see Jacques 2017: 144).

A further apparent obstacle to the hypothesis that Bailang -ə- in open syllables corresponds to Chinese -ə- is the word 'mother' (Bailang 摸 * $\mathrm{m}^{\mathrm{f}} \mathrm{a}>\mathrm{ma}$ 母 [28d], OChi. *mə?). One is free to conclude either that Bailang does not distinguish -a- and -ə-, in which case there is a need to explain why the Chinese transcriber choose the transcriptions he chooses, or that the quality of the vowel in the Chinese is innovative in this word.

Final labials: There are three words transcribed with final labials.

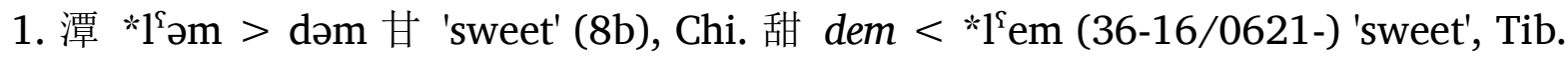

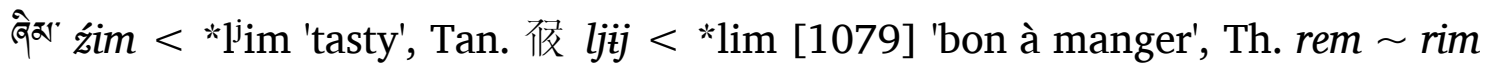
'beer drunk during the death ritual'. The cognates point to *-im or *-em.

2. 尋 *s-ləm > zim 和 'harmonious' (22c) 〜 潯 *s-ləm > zim 溫 'warm' (23b). Chi. 尋 zim <*sə-1[ə]m (38-17/0662a) 'warm up (food)', Bur. ọ lum 'warm', Tan. 获 low $^{2}<$ *lvm (0115) 'chaud', Jinghpaw lum ${ }^{33}$ 'tiède' (Jacques 2014: 198, cf. Xu et al. 1983). The cognates point to or are compatible with *-um.

3. 淫 *ləm > jim 家 'home, family' (39d). Chi. 窨 'imH $<* \mathrm{q}(\mathrm{r})$ [ə]m-s (653-)

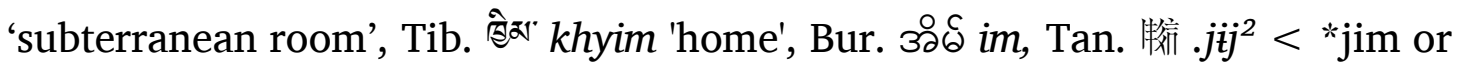
*C-tçim (2560), Situ Rgy. ta-tç̂m, Pumi tढ̆̃̃ (Jacques 2014: 186). The cognates point clearly to -im.

Among these words 'sweet' and 'home' point to the vowel -i-, and 'warm' points to -u-. It is noteworthy that nowhere in the transcription of the three Bailang poems is a characters used with an OChi. reading with the rime *-im. This fact points toward the absence of this rhyme in Bailang, and a Bailang internal change *-im $>-ə m .{ }^{56}$ One 
could suggest that Bailang also changed *-um as *-əm, but as Chinese would have no way to write /-um/ distinctly from /om/ in this period (Baxter 1992: 551-552), it is equally possible that the Bailang word for 'warm' was *slum.

Final velars: There are four relevant words transcribed with final velars. One must remember that both Tibetan and Burmese merged -e- and -i- before velars (Dempsey's law), so the witness of Chinese cognates is particularly important in these cases.

1. 陵 *roy > lin 之 (16c) Tib. 卷 glin 'continent, island, garden', Chi. 田 den <

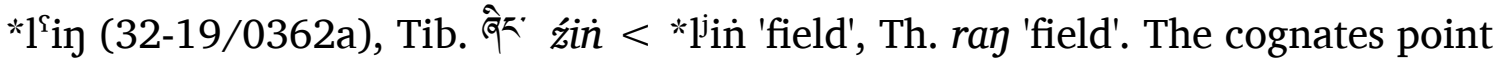
to *-i-.

2. 鱗 *rin > lin 長 'long' (13d) 陵 *rə⿹ > lin 長 'long' (44a). Tib. रิ₹ rin, Bur.

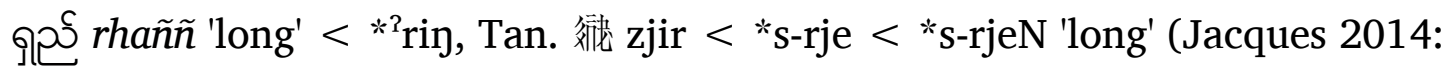
101). The cognates point to -i- or -e-

3. 仍 *nəy > ńị 心 'heart' (28a). Chi. 仁 nyin < *nin (32-28/0388f) 'kindness', Tib.

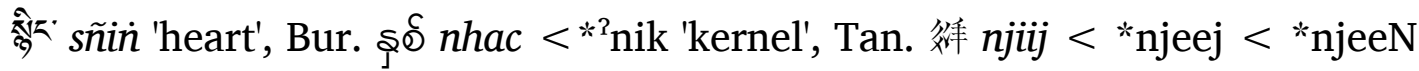
'coeur', Japhug Rgy. tu-sni. The cognates generally point to *-i-.

4. 息 *sək > sik 木 'wood' (39a). Chi. 薪 $\sin <$ *si[p] 'firewood' (32-33/0382n), Tib.

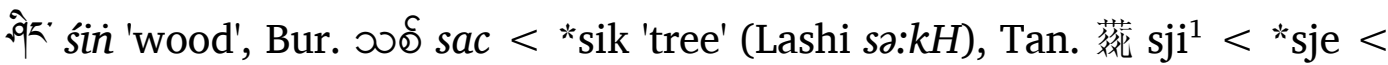
*sjeN (4250) 'bois, arbre'. ${ }^{57}$ The cognates point to *-i-.

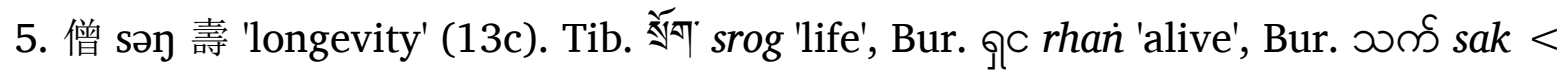
${ }^{* 2}$ sak 'life' (Lashi - $\left.{ }^{2} s a k H\right)$, and Chi.' sik < *sək (05-29/0925a) 'breath'. The cognates point to -*ə- with some complications.

In four cases the cognates point to -i- and in the weakest case they point to -əPossible interpretations include: 1. Bailang changed *-iK to -əK (cf. Lashi sə:kH 'tree'), perhaps merging with inherited -əK, and the Chinese transcription faithfully reflects

Chinese the coincidence of the Han reading 淫 /jim/ for 'home' with its Burmese and Tangut cognates suggests that this character was chosen precisely to match a pronunciation [im]. This proposal is untenable for two reasons. First, it draws the Bailang reading of 潯 'warm' further away from its putative cognates; to write *-um as -im is not acceptable if -əm were also available. Second, and more importantly, the Han vowel in 'sweet' is -ə-, so a proposed Bailang internal change *-im > -əm is still required. Thus, the suggestion that the vowels of the transcriptional dialect were close to the Han pronunciations in these three words, although tempting for 'home', creates more problems than it solves. 57 There is an inconsistency in Jacques' pre-Tangut reconstruction. Sometimes he suggests *eN changes to *-e (e.g. Tan. 菻 $s j{ }^{1}<*$ sje < *sjeN [4250] 'bois, arbre', p. 100) and sometimes to *-ej (e.g. Tan. 哴 mjiij $^{2}<$ *mjeej < *mjeeN [2639] 'nom', p. 169). Hill (2015: 194) proposes to instead reconstruct *sjiN and *mjeeN to match the vowels of Chinese 薪 $\sin <$ *si[n] 'firewood' and Chi. 名 mjieng < *C.men (0931a/0826a). 
the latter, 2. Bailang maintains -iK in 'field', 'long', 'heart' and 'wood', but the Chinese transcriptional dialect was unable to transcribe this as such, so settled for -əK as an approximation. In this case, one can either dismiss the cognate proposals associated with 僧 səy 壽 'longevity' (13c), supposing that the Bailang pronunciation was /sin/ or one can suppose that Bailang maintained -in and -əy separately, with -əy in this word, the two sounds merging only in the transcription. The evidence of 'long' points toward the second proposal. In Chinese velar nasals and dental nasals are difficult to distinguish after the vowel -i-; the distinction was probably lost before the period of this poem (Baxter 1992: 423). Consequently, the alternative transcription 鱗 *rin is not evidence against Bailang *rin. It appears the Bailang is *rin, a syllable absent in the Chinese transcriptional dialect, which was transcribed once as 鱗 rin $>$ lin with the correct vowel but an incorrect final, and once as 陵 rəy $>$ lin with the correct final but an incorrect vowel.

Final - $i$ : There are two words transcribed with final $-i$.

1. 存 * $\mathrm{dz}^{\mathrm{S}}$ ən $>$ dzən (to be read /dzəi/) 熾 'glorious' (14d). Tib. ॠळన' mtshar 'fair, beautiful, bright', Chi. 粲 tshanH $<{ }^{*} \mathrm{ts}^{\mathrm{hs}}$ ars (25-40/0154b) 'bright and white'. Cognates point to -a-.

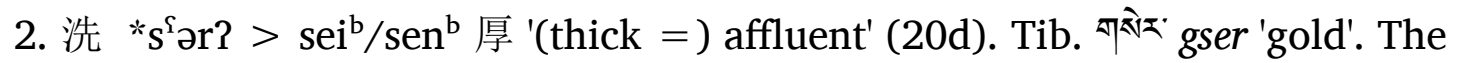
cognate points to -e-.

A closeness of the Chinese transcriptional to Han Chinese rather than Old Chinese in this phonetic environment is capable of explaining the divergent vowels of the proposed cognates. A reading 洗 $/ \mathrm{se}^{\mathrm{b}} /$ is an excellent match to the proposed Tibetan cognate. The match between Bailang 存 /dzəi/ 儎 'glorious' (14d) and Chi. 粲 tshanH $<* t^{\mathrm{hs}}$ ars is not quite so good, as one would prefer to see -ə- in the Chinese cognate, but a correspondence between Bailang -ə- and Chinese -a- is also met in 'hundred' (理

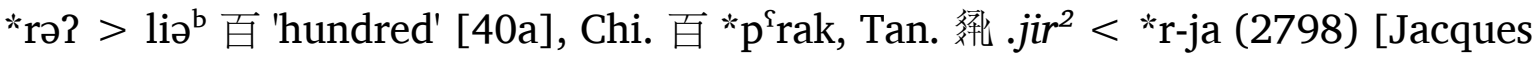
2014: 92]). This passage suggests that the irregular phonetic development of 存 (i.e.

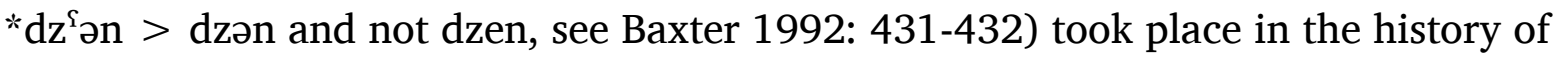
the transcriptional dialect, and preceded the change of *-r $>\mathrm{i}$ (or $-\mathrm{n}$ in the dialect ancestral to MChi.).

This discussion permit the following tentative conclusions. The transcriptional dialect was closer to the Han reading for 衣 *2əi(s) > $\operatorname{iii}^{c}\left(^{c}\right)$ 風 '(wind $=$ ) custom' (5b) and 洗 " ${ }^{\mathrm{S}}$ כr? $>\mathrm{sei}^{\mathrm{b}} / \mathrm{sen}^{\mathrm{b}}$ 厚 '(thick $=$ ) affluent' (20d) but closer to the OChi. reading for 淫 *ləm > jim 家 'home, family' (39d). It is unclear to what extent the Bailang difference between -ə- and -a- reflects an inherited distinction-'love' (杽 *dzəs > 
dziəc 慈 'loving' [28c]. OChi. 慈 *dzə, Tan. 灵 $d z u^{1}<*$ *ndə strongly suggests that it is, but 'glorious' (存 /dzəi/ [14d], Chi. 粲 tshanH < *ts ${ }^{\text {hs }}$ ars), 'hundred' (理 *rə? $>$ liə ${ }^{\mathrm{b}}$

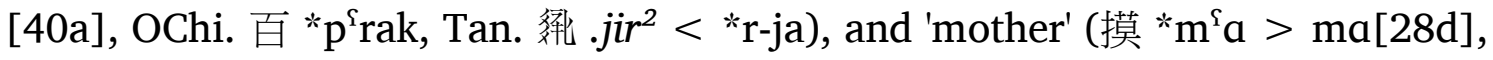
OChi. *mə?) do not. Even if Bailang -ə- is partly inherited one would not expect its value to match that of OChi. all the time. Bailang maintains a rime -in, which the Chinese transcriber was ill equipped to handle, usually writing /əy/, but in one case /in/. Returning full circle to 繩 *ləys > jin c , *m-ləy > źin 慕 'long for' (17a) and 陽 *lay > jay 願 'wish, desire' (13a, 14b), Coblin may well be right that these words are cognate, but it does not seem likely that they are two attempts to right the same word. ${ }^{58}$ It is relevant to mention that there is some evidence that -ə- and -a-, were considered to rhyme in Bailang (vide infra), but it would be premature to draw any conclusions from this evidence about Bailang phonology.

13b. 雒 * $\mathrm{r}^{\mathrm{r}} \mathrm{ak}>$ lak 主 'ruler'. The possibly cognates Tib. 害 rje < *rl'e 'lord' and Tamang ${ }^{4} k l e$ 'king' come to mind (see Jacques 2004), but because of the difference in Auslaut are probably to be rejected. Beckwith's speculation that transcriptional Chinese $-\mathrm{k}$ reflects Bailang - 1 would improve these comparisons (2008: 94). Zhengzhang (1993:

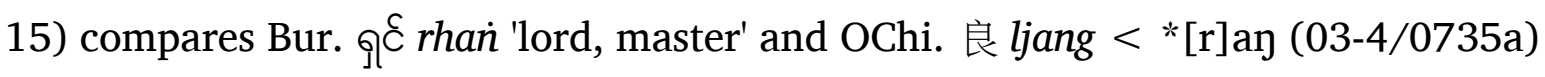
'good'. This word recurs at $18 \mathrm{~d}$.

13c. 僧 $\mathrm{s}^{59}$ 壽 'longevity'. Coblin speculates that this word “may mean 'long life' or perhaps simply 'life'” (1979: 189). He compares WBur. ९̣ rhan 'alive' (1979: 209 note 68, also cf. Benedict 1979: 85 \#404). If Coblin's suggested meaning is correct, one can

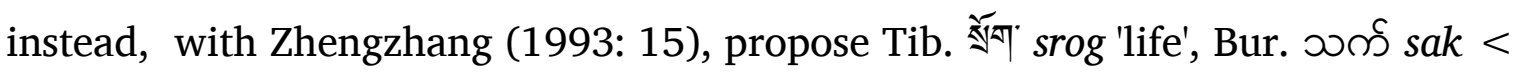
${ }^{*}$ 'sak 'life' (Lashi - $\left.{ }^{2} s a k H\right)$, and Chi. 息 sik < *sək (05-29/0925a) 'breath', although the velar nasal in Bailang is unexpected. On the development of OChi. *-ə- in the Chinese transcriptional dialect see discussion at $13 \mathrm{a}$.

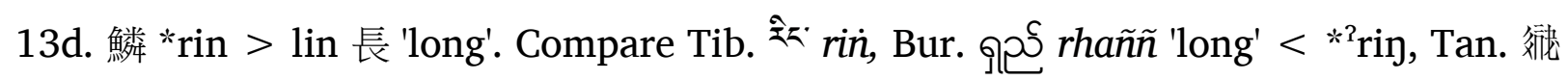

58 For the convenience of the reader I also assemble those Bailang words that are transcribed with characters that have OChi. *-ə- readings without proposed Trans-Himalayan cognates and omitting

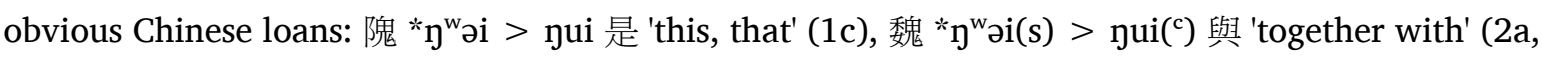

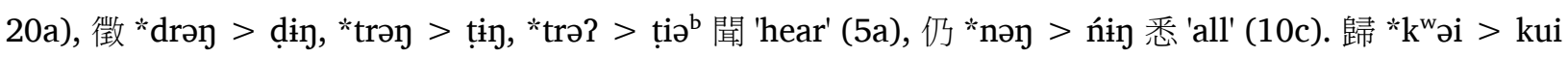
歷 'pass through' (25c), 微 *məi > mui 風 '(wind =) news, accounts' (33d), 側 *tsrək > tṣik! 'large

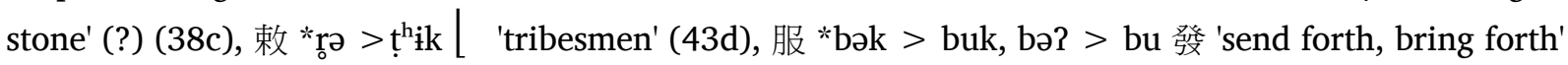
(39c). For the last, Coblin in fact compares 呟' hphro 'scatter, emanate' (1979: 209 note 40), but this comparison is not credible (see comm. to 39c).

59 This character is not used in early texts, but is first attested in the Han dynasty and is used to transliterate the first syllable of samgha-; it has no OChi. reading (see Shuessler 2009: 117). 
zjir < *s-rje < *s-rjeN 'long', and with weaker but plausible semantics OChi. 引 yinX $<$ *li[n]? 'draw the bow' (Zhengzhang 1993: 15, Jacques 2014: 101). Ma \& Dai offer further cognates (1982: 22-23). The same word appears as 陵 *roy > lin 長 'long' at 44a. See discussion at 13 a.

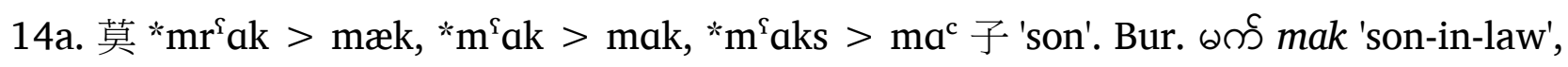

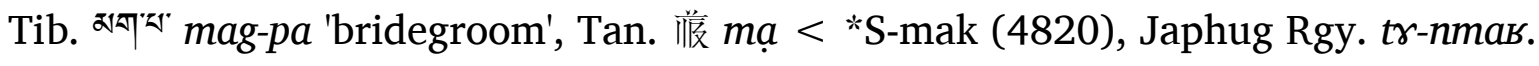
The comparisons suggest the character was not read ${ }^{*} \mathrm{~m}^{\mathrm{f}} \mathrm{aks}>\mathrm{ma}^{\mathrm{c}}$, since this would be missing the final velar stop in the transcriptional dialect (see discussion at $4 \mathrm{~b}$ ), although it would perhaps be somewhat surprising for the transcriber to use one Chinese character intending two different readings in such a short span.

14b. 稚 *dris > dic 孫 'grandson'. Zhengzhang (1993: 15) compares WBur. 66\%: mreh <

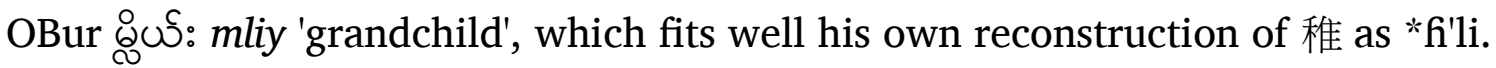
14c. 角 * $k r^{\mathrm{s}} \mathrm{ok}>\mathrm{kok}$ 昌 'splendid'.

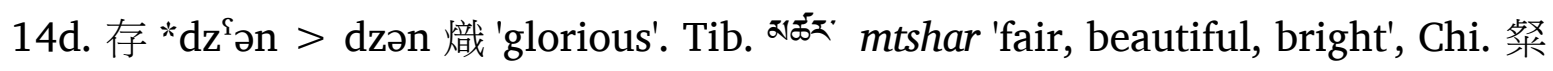
tshanH $<*{ }^{\mathrm{hs}}{ }^{\mathrm{hs}}$ ars (25-40/0154b) 'bright and white'. Baxter \& Sagart's (2011) reconstruction 存 $d z$ won $<*[\mathrm{dz}]^{\text {` } \partial[\mathrm{n}]}(33-22 / 0432 \mathrm{a})$ allows for a final *-r. On the development of OChi. *-ว- in the Chinese transcriptional dialect see discussion at 13a.

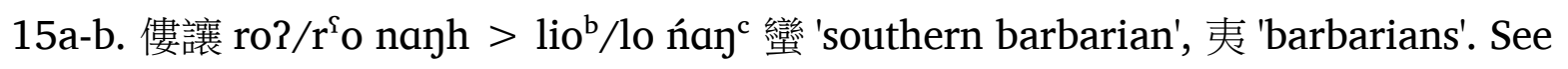
etymological discussion at 11a-b. For the development of rhotics in the Chinese transcriptional dialect see the discussion at $11 \mathrm{a}-\mathrm{b}$.

15c. 皮 *bai > biæi 所 relative clause nominalizer. Dong “(1937: 4) suggests that the character $15 \mathrm{c}$ 皮 is a graphic error for 支 which corresponds to Chinese 所 in line 12” (Coblin 1979: 189).

15d. 尼 * $\mathrm{n}^{\mathrm{S}}$ is > neic, *nri > ṇi 處 'dwell'. OBur. \$ơ niy 'stay' (Zhengzhang 1993: 18).

16a. 且 “ts ${ }^{\mathrm{S}} \mathrm{a}$ ? $>\mathrm{tsa}^{\mathrm{b}}$ 日 'sun'. The word also occurs at 18b. Relying on Benedict (1972: 47 \#187), Coblin proposes the cognates Bahing tśyar, Jinghpaw dźan, and Garo sal (1979: 210 note 86). Coblin (1979: 200) also cites a Lolo-Burmese reconstruction of Bradley *tsa' 'sunshine' (Bradley 1975: 126 \#338), based on such forms as Lahu cha: and Akha $u_{v} t s a^{2}$ (cf. Bradley 1979: 326, \#338A).

16b. 交 * $\mathrm{k}^{\mathrm{S}} \mathrm{raw}>\mathrm{kæu}$ 入 'enter (= set, go down)'. Compare OBur. §ু kla 'fall' and OChi. 落 lak < *kə.r'ak (02-01/0766q') 'fall (v.)' (Zhengzhang 1993: 18).

16c. 陵 *roy > lin 之 possessive or attributive particle. Noting that at 29c the Chinese morpheme $之$ is borrowed directly into Bailang, Coblin wonders whether here the Bailang syllable 陵*rəy > lin does not form a compound with the following syllable 悟 * $\mathrm{\eta}^{\mathrm{f}}$ as $>\mathrm{ya}^{\mathrm{c}}$ 部 'sector' at 16d (1979: 189). Coblin suggests comparison with Tib. Âै' 
glin 'continent, island, garden' (1979: 200), if his speculation is correct, one can

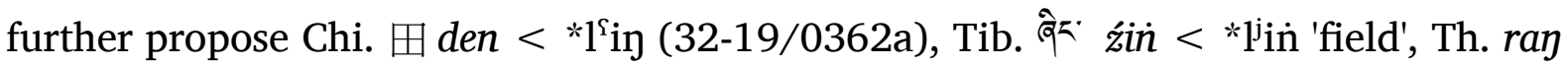
'field', and proto-Tani *ruk (see note 55 above). Zhengzhang (1993: 18) repeats

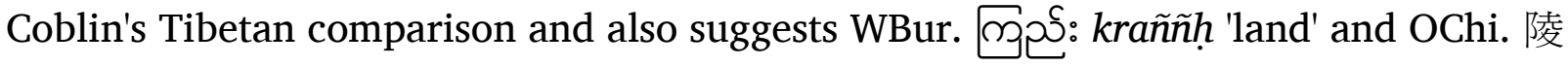
ling $<*[r] ə \eta(06-17 / 0898 c)$ 'mound, hill' as cognates. Note that the medial -1- in Tibetan does not match the (-)r- of Burmese and Chinese. For the development of rhotics in the Chinese transcriptional dialect see the discussion at 11a-b. On the development of OChi. *-ə- in the Chinese transcriptional dialect see discussion at 13a.

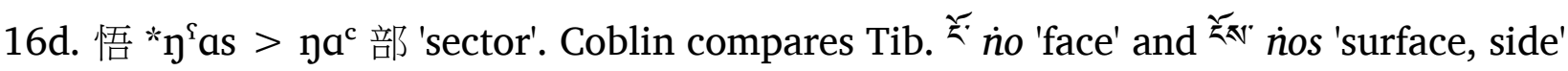
(1979: 202). Jacques further proposes Japhug Rgy. tu-rma 'face' and either Tan. 㱠 $\eta w \partial r^{2}$ (3158) or 陊 $n j i j r^{2}$ (1204) as cognates of Tib. ${ }^{\varkappa}$ no 'face' (Jacques 2014: 163). Zhengzhang (1993: 18) compares the Bailang words with 峨 nga 'lofty' (18-05/0002k), a word that Baxter \& Sagart (1014b) do not reconstruct, for which Schuessler (2009: 212) offers * ${ }^{\text {s}}$ ai. Also see discussion at $16 c$.

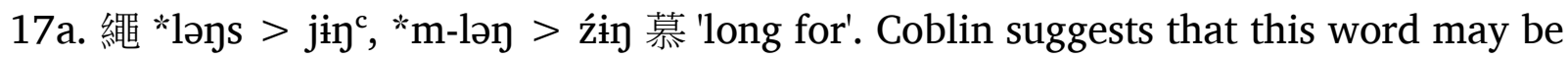
cognate with 陽 *lay > jay 願 'wish, desire' at 13a and 44b (1979: 189). Zhengzhang (1993: 18) compares Bur. ๆरु rañ̃n < *rin 'aim at', Tib. बेव' źen <*1jen or *rjen 'desire, yearn for', and OChi. 憐 len < *rin (32-26/0387l) 'love, pity'. On the development of OChi. *-ə- in the Chinese transcriptional dialect see discussion at 13a.

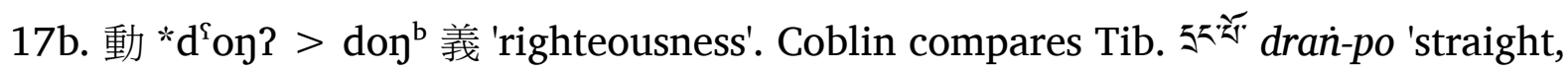
sincere, upright' (1979: 202).

17c. 隨 *s-wai > zyæi 向 'face toward, incline toward'. The phrase 隨旅 s-wai ra? > zyæi lia ${ }^{\mathrm{b}}$ 'face toward the civilizing influence also occurs at 5a-b.

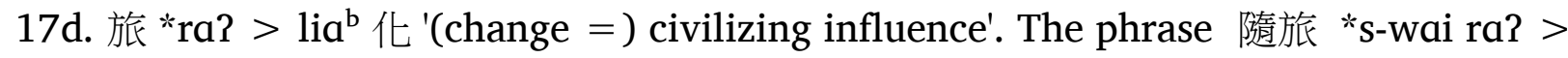
zyæi lia ${ }^{\mathrm{b}}$ 'face toward the civilizing influence also occurs at 5a-b.

18a. 路 * $\mathrm{r}^{\mathrm{S}} \mathrm{aks}>1 \mathrm{a}^{\mathrm{c}}$ 歸 'return'. Keeping in mind that *ks had reduced to -h in the transcriptional dialect (see discussion at $4 \mathrm{~b}$ ), compare $\sim \curvearrowright l \bar{a}$ 'come'. ${ }^{60}$ However, if this word had a rusheng reading in the transcriptional dialect (see discussion at 38b) comparison with Tibetan र्राण' $\log$ 'return' is perhaps more appropriate. For the development of rhotics in the Chinese transcriptional dialect see the discussion at 11a-b. The word 路 * $\mathrm{r}^{\mathrm{S}} \mathrm{aks}>1 \mathrm{la}^{\mathrm{c}}$ 歸 'return' also occurs at $28 \mathrm{~b}$ and 35c.

$18 \mathrm{~b}$. 且 " $\mathrm{ts}^{\mathrm{\Upsilon}} \mathrm{a} 2>\mathrm{tsa}^{\mathrm{b}}$ 日 'sun'. See discussion at $16 \mathrm{a}$.

18c. 㨂 " $\mathrm{t}^{\mathrm{f}} \mathrm{o \eta}$ ? $>$ toj $^{\mathrm{b}}$ 出 'come out'. Neither Schuessler (2009) nor Baxter \& Sagart

60 For another language with r- rather than 1- in 'come' compare Th. rah 'come'. 
(2014b) offer reconstructions of this word. This reconstruction is supplied on the basis of Coblin's reading (1979: 190) and the xiesheng series. Coblin compares the Tibetan

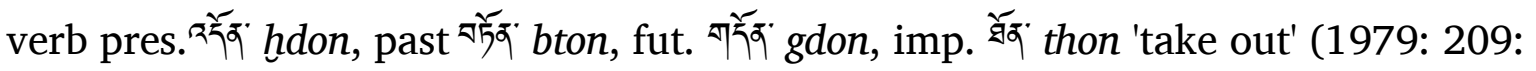
note 47). Perhaps a more straightforward comparison is this verb's intransitive

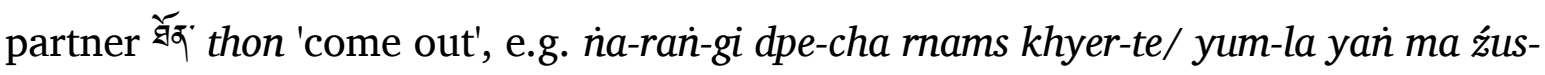
par thon phyin-pas/'I put together my books, came out and left, even without telling the lama's wife' (Mila, de Jong 1959: 68). Nonetheless, the correspondence of Bailang -on with Tibetan -on is perhaps a problem. Zhengzhang (1993: 18) compares WBur.

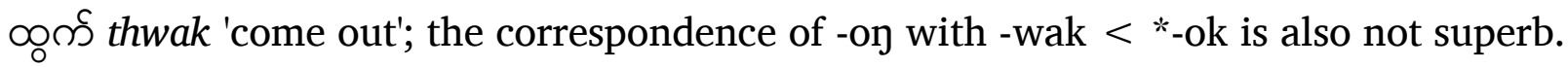
18d. 雒 * $\mathrm{r}^{\mathrm{f}} \mathrm{ak}>\mathrm{læk}$ 主 'ruler'. See discussion at $13 \mathrm{~b}$.

19a. 聖 *lleys $>$ śej $^{c}$ 聖 'sage'. A loan from Chinese.

19b. 德 *t $\mathrm{t}^{\text {` }} \mathrm{k}>$ tək 德 'virtue'. A loan from Chinese. Also occurs at 27d.

19c. 渡 * $\mathrm{d}^{\mathrm{f}} \mathrm{aks}>\mathrm{da}^{\mathrm{c}}$ 恩 'kindness'. Coblin tentatively identifies this word with 度 * $\mathrm{d}^{\mathrm{f}} \mathrm{ak}>$ $\mathrm{dak}, \mathrm{d}^{\mathrm{f}} \mathrm{aks}>\mathrm{da}^{\mathrm{c}}$ 富 'rich' at 20c, “both possibly meaning 'thick'” (1979: 190). For

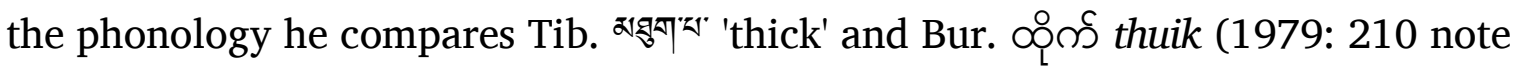
100) and for the semantics 厚 hòu “thick, substantial, rich, generous, kind" (1979: 190). The identification of the two Bailang words may be correct, but the proposed cognates are not. The Bailang word has a different main vowel from the Tibetan comparison. The Burmese comparison I have difficulty confirming. Perhaps Judson's

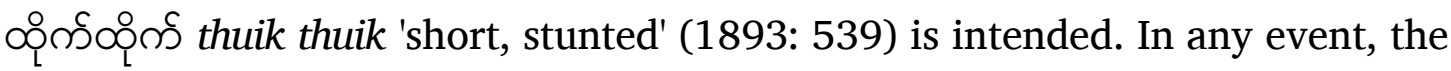
Burmese word is unlikely to be cognate to the Tibetan; most researchers believe that the rime -uik in Burmese is indicative of loans (Luce 1985: vol. I, 100, Pulleyblank

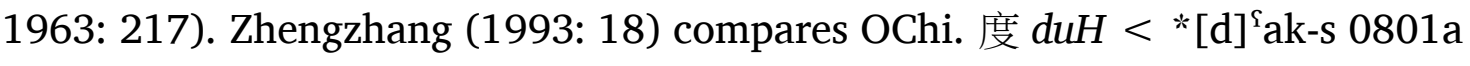
'measure (n.)', a perfect phonological match, but semantically weak. He also proposes that this Chinese word is cognate to Bailang 度 at $12 \mathrm{c}$; he thus implies that 度 (at $12 \mathrm{c}$ and 20c) and 渡 both transcribe the same Bailang word, perhaps with a Gesamtbedeutung 'largess'.

19d. 諾 “ $\mathrm{n}^{\text {§ }}$ ak > nak 深 'deep'. Bur. \$ố nak 'deep' (cf. Ma \& Dai 1982: 22, Zhengzhang 1993: 18), Tan. 淡 $n a<* n a k$ (4693), Japhug Rgy. тпав (Jacques 2014: 131-132). 20a. 魏 * $\eta^{w}$ əi(s) $>$ pui( $\left(^{c}\right)$ 與 'together with' also occurs at 2 a.

20b. 菌 *gun? > guin ${ }^{\text {b }}$ 人 'people, men'. Compare Tib. गुす̆ kun 'all' (see Hill 2007: 481482), Bur. зə๓ฺฐ akun < *gun 'all'. ${ }^{61}$ In the transcriptional Chinese dialect -u- had already broken to -uə- before dentals (cf. note 21). The same Bailang word is glossed 部

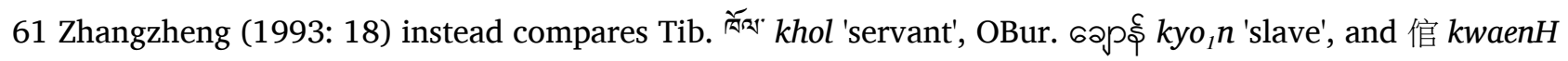
$<{ }^{*} \mathrm{k}^{\mathrm{ws}} \mathrm{ra}$ [n]-s (25-01/0157l) 'servant, groom'. 
'tribe' at 24a and 同 'some, together' at 41c.

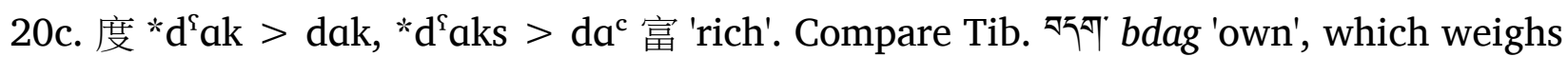

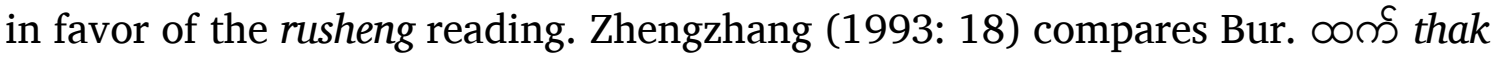
'sharp, keen, powerful'.

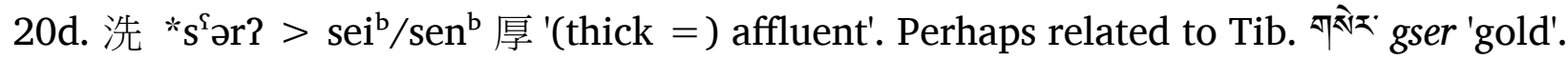

On the development of OChi. *-ə- in the Chinese transcriptional dialect see discussion at $13 a$.

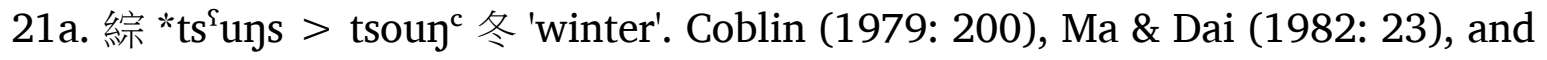
Zhengzhang (1993: 18) compare WBur. 6a0sc: chorị < *tsupḥ 'cool season'. Jacques compares this Burmese word to Tan. 萡 tsur < *r-tso (1490) 'hiver' and Japhug Rgy. qartsu, but the correspondence of the rimes is unexpected (Jacques 2014: 67). Ma \& Dai's (1982: 24) comparison to Jinghpaw $n^{31} \int u \eta^{33}$ (from $n i \eta^{31} \int u \eta^{33}$ acc. to Xu et al. 1983) also merits mention. Zhengzhang also compares Chinese 冬 towng < * $t^{\mathrm{f}} \mathrm{u}$ (1503/1002a) 'winter', which is perhaps possible despite the irregular initial correspondence.

21b. 邪 *ja > jæ, *s-la > ziæ, *s-la > zia 多 'much'. Also occurs at 7a, 22b and 24c. 21c. 流 *ru > liu 霜 'frost'. Zhengzhang (1993: 18) compares Bur. 6ㅔ mrū 'haze'.

21d. 藩 *par (cf. note 38) > puan 雪 'snow'. Compare Tan. 校.wji < *C-S-pja (4091) 'neige' and Japhug Rgy. tr-jpa. According to Jacques there are cognates in LoloBurmese languages (2014: 87). On the basis of Bradley's comment that there "is a word for snow even in many languages now spoken too far south to see it, and used instead for hail" (1979: 29), one can presume that Jacques has in mind Bradley's * $\mathrm{wa}^{2}$ 'hail', reconstructed on the basis of Lahu $v a^{2}$ and Lisu $w a^{5}\left(m a^{4}\right) s i^{5}$ (1979: 324-325, \#325). ${ }^{62}$ Ma \& Dai offer related forms in further languages (1982: 23). Perhaps comparison with Chi. 㺕 $b a<*[b]^{\text {S }}$ ar (24-54/0195r) 'white, white-haired' and Mizo $v \bar{a} r$ 'white' is not unreasonable.

22a. 莋 $* \mathrm{dz}^{\mathrm{S}} \mathrm{ak}>\mathrm{dzak}$ 夏 'summer'.

22b. 邪 *ja > jæ, s-la > ziæ, s-la > zia 多 'much'. Also occurs at 7a, 21b and 24c. 22c. 尋 *s-ləm > zim 和 'harmonious'. Probably the same word as 潯 *s-ləm > zim 溫 'warm' at 23b (Coblin 1979: 191, Zhengzhang 1993: 19). On the development of OChi. *-ə- in the Chinese transcriptional dialect see discussion at 13a. 22d. 螺 * $\mathrm{r}^{\mathrm{s}} \mathrm{oi}>$ luai 雨 'rain'. Chi. 雨 $h j u X<{ }^{*} \mathrm{C} . \mathrm{G}^{\mathrm{w}}(\mathrm{r}) \mathrm{a}$ ? (01-26/0100a), Bur. ø $r w \bar{a}$ 'rain' (see Ma \& Dai 1982: 23, Zhengzhang 1993: 19). Remember *-o- had already broken to -ua- before dentals (and $-\mathrm{j}$ ) in the Chinese transcriptional dialect (cf. note 21).

62 It is unclear what Bradley intends by the use of parentheses in the Lisu form. 
Consequently, 螺 should be understood as $/ \mathrm{r}^{\mathrm{f}} \mathrm{uai} /$. Also see discussion at 11a-b. 23a. 藐 *mr ${ }^{\mathrm{f}}$ auk $>$ mok $>$ maewk 寒 'cold'.

23b. 潯 *s-ləm > zim 溫 'warm'. Chi. 尋 zim < *sə-1[ə]m (38-17/0662a) 'warm up (food)', Bur. @̊ lum 'warm', Tan. 获 low ${ }^{2}<$ *lvm (0115) 'chaud' ${ }^{63}$, Jinghpaw lūm 'tiède' (Jacques 2014: 198). ${ }^{64}$ Probably the same word as 尋 *s-ləm > zim 和 'harmonious' at 22c (Coblin 1979: 191, Zhengzhang 1993: 19). The proposed cognates show that the transcriptional dialect must have preserved the sl- cluster of Old Chinese. The comparison of Bailang 蘇 * $s y^{\S} a>$ sa 肉 'meat' (9c) to Tib. 97 'sa 'flesh', etc. shows that in other cases s- initial clusters had simplified. On the development of laterals in the Chinese transcriptional dialect see the discussion at 39d. On the development of OChi. *-ə- in the Chinese transcriptional dialect see discussion at 13a.

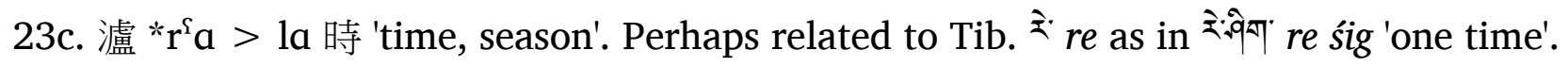

For the development of rhotics in the Chinese transcriptional dialect see the discussion at $11 \mathrm{a}-\mathrm{b}$.

23d. 漓 *rai > liæi 適 'suitable, in balance'. See discussion at 10d.

24a. 菌 *gun? > guin ${ }^{\text {b }}$ 部 'tribe'. The same word is glossed 人 'people, men' at 20b.

24b. 補 " $\mathrm{p}^{\mathrm{s}} \mathrm{a}$ ? > $\mathrm{pa}^{\mathrm{b}}$ 人 'person'. Chi. 夫 *-pa (as in 田夫 *1in-pa 'farmer', cf. 田 *1'in

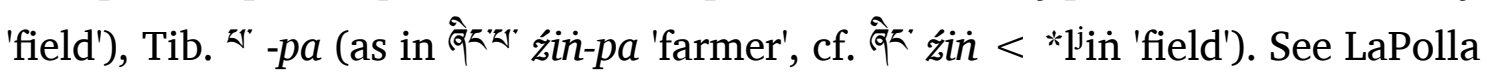
(2003: 27).

24c. 邪 *ja > jæ, s-la > ziæ, s-la > zia 多 'much'. Also occurs at 7a., 21b. and 22b.

24d. 推 ${ }^{*} \mathrm{t}^{\mathrm{hs}} \mathrm{ui}>\mathrm{t}^{\mathrm{h}} \mathrm{uəi}, \mathrm{t}^{\mathrm{h}} \mathrm{ui}>\mathrm{t}^{\mathrm{h}}{ }^{\mathrm{u}}$ i 有 'have'. In the transcriptional Chinese dialect -ui had already broken to -uəi (cf. note 21).

25a. 辟 * $\mathrm{b}^{\mathrm{f}} \mathrm{ek}>$ bek, bek > biek, pek > piek 涉 'traverse'. Compare Limbu pekma 'go' (Michailovsky 2002). Zhengzhang (1993: 19) compares OBur. ঠুণ seems unlikely.

25b. 危 “yoi > yyæi 危 'danger'. A loan from Chinese.

25c. 歸 * $\mathrm{k}^{\mathrm{w}}$ əi > kui 歷 'pass through'. On the development of OChi. *-ə- in the Chinese transcriptional dialect see discussion at 13a.

25d. 險 *ioram? > hiæm, Đ̊ram? > hiam 險 'peril'. Zhengzhang (1993: 19) compares Tib.

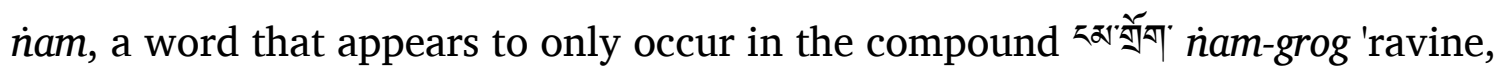
canyon'. A loan from Chinese appears more likely, in particular as Baxter \& Sagart (2014b) reconstruct 險 $x j a e m X<{ }^{*} \mathrm{q}^{\mathrm{h}} \mathrm{r}[\mathrm{a}] \mathrm{m}$ ? (36-06/0613f) 'precipitous, dangerous', without the velar nasal initial. This word also occurs at $36 \mathrm{c}$.

63 In the pre-Tangut reconstruction 'v' in this context means a "voyelle autre que i" (Jacques 2014: 193). 64 Bodman suggests comparing Tib. गढुహ" gtum 'fierce, hot, angry', reconstructing *glum (1980: 539). 
26a. 莫 * $m r^{\mathrm{f}} \mathrm{ak}>\mathrm{mæk}, \mathrm{m}^{\mathrm{i}} \mathrm{ak}>\mathrm{mak}, \mathrm{m}^{\mathrm{f}} \mathrm{aks}>\mathrm{ma}^{\mathrm{c}}$ 不 'not (verbal negative)'. See discussion at $4 \mathrm{~b}$.

26b. 受 *du2 > dźu ${ }^{\mathrm{b}}$ 遠 'consider to be (too) far'. Zhengzhang (1993: 19) compares WBur. Ф: cuih 'worry', OChi. 愁 dzrjuw < *[dz]riw (13-57/1092i) 'grieved'.

26c. 萬 * $m^{\mathrm{f}}$ ans $>$ muan $^{\mathrm{c}}$ 萬 'ten thousand'. A Chinese loanword.

26d. 柳 *ru? > luib 里 'li'. A Chinese loan of 里 liX < *ro? (04-35/0978a) 'measure of distance'. It is odd that in a loanword the Bailang vowel would not match the Chinese vowel.

27a. 術 *m-lut > źuit 去 'depart from; cast away'. Zhengzhang (1993: 19) compares Tib. 5ૉ' 'crumble, collapse'.

27b. 疊 * $1^{\mathrm{S}} \mathrm{ep}>$ dep 俗 'vulgar, common'. Zhengzhang (1993: 19) compares Bur. œ。ㅇํㅇ thuṃh 'custom, tradition'. I am tempted to compare Tib. ओेন' leb 'flat', itself cognate to OBur. חুर् klap 'kyat'.

27c. 附 *boh > buoc 歸 'return to'. Zhengzhang (1993: 19) compares Bur. 을 pūh 'be close together, bring together' and OChi. 附 bjuH < *N-p(r)o?-s (10-39/0136k) 'be attached to'.

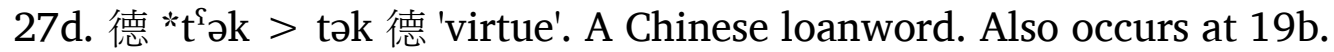

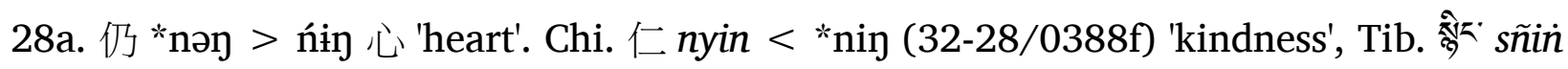
'heart', Bur. §र्ठ nhac <*3nik 'kernel', ${ }^{65}$ Tan. 烽 njiij < *njeej < *njeeN 'coeur', Japhug Rgy. tu-sni (cf. Ma \& Dai 1982: 23-24 and Zhengzhang 1993: 19). Note that for this word Bailang patterns with Tibetan in having a velar nasal final rather than a velar stop final, but in the word 息 *sək > sik 木 'wood' (39a) the velar stop final of Bailang patterns with the Burmish languages (Bur. כలీ sac < *sik 'tree', Lashi sə:kH) against

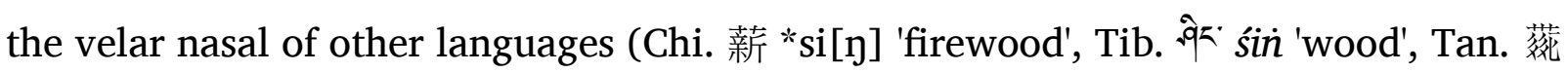
sji $^{1}<{ }^{*}$ sje < *sjeN [4250] 'bois, arbre'). On the development of OChi. *-ə- in the Chinese transcriptional dialect see discussion at 13a.

28b. 路 * $\mathrm{r}^{\mathrm{S}} \mathrm{aks}>1 \mathrm{a}^{\mathrm{c}}$ 歸 'return'. See discussion at 18a.

28c. 杽 *dzəs > dziəc 慈 'loving'. Chi. 慈 $d z i<*$ *dzə (04-49/0966j) 'kind adj.', Tib. ॠER mdzah 'love', Bur. os cā, Tan. 灵 $d z u^{1}<$ *ndə (1338). Zhengzhang (1993: 19) sees as a Chinese loan, a very unlikely possibility. On the development of OChi. *-ə- in the Chinese transcriptional dialect see discussion at 13a.

28d. 摸 * $\mathrm{m}^{\mathrm{f}} \mathrm{a}>\mathrm{ma}$ 母 'mother'. Chi. 母 $m u w X<* m ə$ ? (04-64/0947a) 'mother', Tib. a゙' ma,

65 Although the linguistics literature often cites a word इळీ nhac 'heart' (e.g. Matisoff 2003: 480). In fact, the Written Burmese word for 'heart' is \$๐̣ nha-lum and there is another word зəฐ์ anhac 'kernel, core'. One may plausibly speculate that \$̦̣ nha-lum was once spelled *nhac-lum but I have not confirmed this. 
Bur. 6 ma. Zhengzhang (1993: 19) sees as a Chinese loan, a very unlikely possibility. 29a-b. 荒服 * ${ }^{\mathrm{s}} \mathrm{a}$ a bək / bə2 > huạ buk / bu 荒服 'Huāngfù region'. A loan from Chinese.

29c. 之*tə > tśə > tśi 之, a possessive or attributive particle, perhaps a Chinese borrowing (Zhengzhang 1993: 64).

29d. 儀 *yai > jiæi 外 'outside'. Zhengzhang (1993: 64) sees as a borrowing from Chi. 外 ngwajH $<*[\mathrm{y}]^{\mathrm{ws}} \mathrm{a}[\mathrm{t}]-\mathrm{s}$ 'outside', a distinct possibility.

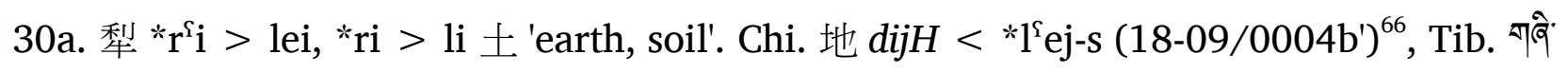
gźi < *glji 'ground', OBur. ઢু心 1993: 64). For the development of rhotics in the Chinese transcriptional dialect see the discussion at $11 \mathrm{a}-\mathrm{b}$.

30b. 籍 * $\mathrm{dz}\left({ }^{\S}\right)$ ak $>$ dziak 地 'earth'.

30c. 憐 * $\mathrm{r}^{\mathrm{S}}$ in > len 墝 'hard, stony'. Zhengzhang (1993: 64) compares Tib. ऐેr ren 'stiff'.

30d. 憐 *r $\mathrm{r}^{\mathrm{i}}$ in $>$ len 埆 'hard, stony'.

31a. 阻 “tsra? > tṣæ ${ }^{\mathrm{b}}$ 食 'eat'. Ch. 咀 $d z j o X<* d z a ?$ (0046u), Tib. ’ $z a<* d z a$

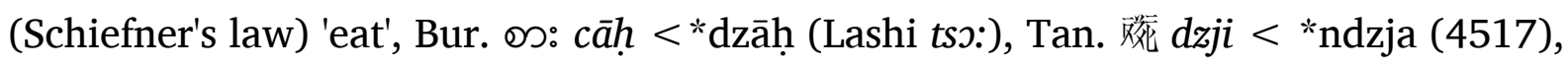

Japhug Rgy. ndza (cf. Ma \& Dai 1992: 23-24, Zhengzhang 1993: 64).

31b. 蘇 * $s \eta^{\mathrm{\complement}} \mathrm{a}>$ sa 肉 'meat'. See discussion at 9c.

31c. 邪 *ja > jæ, *s-la > ziæ, *s-la > zia 衣 'wear'.

31d. 犁 * $\mathrm{r}^{\mathrm{S}} \mathrm{i}>$ lei, *ri > li 皮 'skin'. Coblin (1979: 210 note 83) and Zhengzhang (1993:

64) compare WBur. зə6९ $a$-re < OBur. *a-riy 'skin'; also compare Tan. 菜 $d \not z j i<$ *ndri $<$ *nri (1153), Japhug Rgy. tuu-ndži, and Pumi râ (cf. Jacques 2014: 162). For the development of rhotics in the Chinese transcriptional dialect see the discussion at $11 \mathrm{a}-\mathrm{b}$.

32a. 莫 ${ }^{*} m r^{\mathrm{s}} a k>m æ k,{ }^{*} m^{\mathrm{s} a k}>\mathrm{mak},{ }^{*} \mathrm{~m}^{\mathrm{s}} \mathrm{aks}>\mathrm{ma}^{\mathrm{c}}$ 不 'not (verbal negative)'. See discussion at $4 \mathrm{~b}$.

32b. 碭 * $1^{\text {s }}$ ays $>$ day $^{c}$ 見 'see'. See discussion at $6 b$.

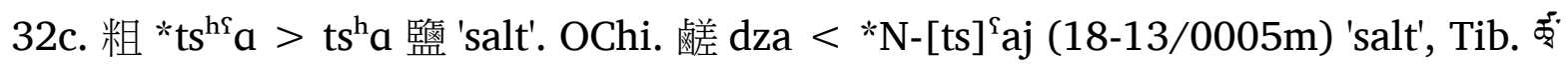
tshwa, Bur. ๖o: chāh < *tsāḥ (Lashi tshoH) (also cf. Ma \& Dai 1982: 24, Zhengzhang 1993: 64), Tan. 低 $t s h j i$ < *tshji or *tshjvC (5186), the “correspondance ... est absolument irrégulière" (Jacques 2014: 164). This is more likely a Wanderwort than genuine cognate among these languages.

32d. 沐 *mºk > mok 穀 'grain'. Coblin compares Tib. 종' hbbru < *hmru (Simon's law) 'grain' and Bur. @ొฏ๊: myuih 'type, class' (1979: 200 note 61, cf. Benedict 1972: 43

66 Bodman reports that 地 has an addition reading ${ }^{*} l^{\Upsilon}$ is that makes the correspondence regular (1980: 99). 
\#150). Zhengzhang (1993: 64) omits the Tibetan comparison but adds Chi. 䴷 mjuw (13-77/1110d) 'barley', which Baxter \& Sagart (2014b) do not reconstruct, but which Schuessler (2009: 184) reconstructs *mu. These comparisons are not compelling, either with the Bailang word or with each other.

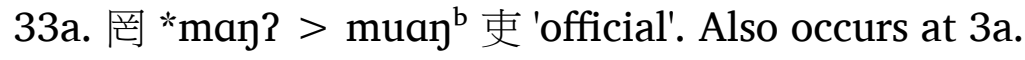

33b. 驛 *lak > jæk jak 譯 'translator'. Also occurs at 3b.

33c. 傳 *dron > dyæn 傳 'transmit'. Also occurs at 43a.

33d. 微 *məi > mui 風 ' (wind =) news, accounts'. On the development of OChi. *-ə- in the Chinese transcriptional dialect see discussion at 13a.

34a. 是 *de? $>d z ́ e^{b}$ 大 'great'. See discussion at 1a.

34b. 漢 "hईars $>$ han $^{\mathrm{c}}$ 漢 'Han'. See discussion at $1 \mathrm{~b}$.

34c. 夜 *jaks $>\mathrm{ja}^{\mathrm{c}}$ 安 'peaceful'.

34d. 拒 "ga? $>$ gia $^{\mathrm{b}}, \mathrm{k}^{\mathrm{w}} \mathrm{a}$ ? $>\mathrm{kya}^{\mathrm{b}}$ 樂 'happy'. See discussion at $9 \mathrm{~b}$.

35a. 蹤 *tson > tsion 攜 'take by the hand'. WBur. 6200经 chon (-on < *-un) 'carry'

(Zhengzhang 1993: 64), Tib. Vzun < *dzun (pres. å̃gj hdzind) 'take'.

35b. 優 * $2 u>2 u$ 負 'carry on the back'. Tan. 榷 .u (2847) 'porter'.

35c. 路 * $\mathrm{r}^{\mathrm{r}} \mathrm{aks}>1 \mathrm{a}^{\mathrm{c}}$ 歸 'return'. See discussion at 18a.

35d. 仁 *nin > ńin 仁 'humaneness'. A loan from Chinese.

36a. 雷 ' $r^{\S} u i$ > luəi 觸 'encounter, butt into'. Zhengzhang (1993: 65) proposes comparison with Bur. ơ: lūḥ 'daub, put on, toss, writhe'.

36b. 折 * $\mathrm{d}^{\mathrm{S} e}>$ de, *det $>$ dźat, *tet $>$ tśat 冒 'risk, brave'.

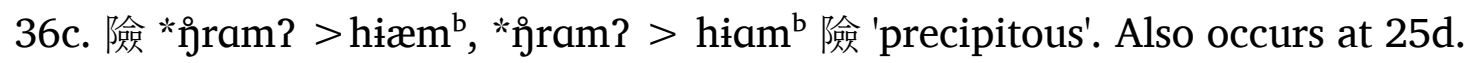

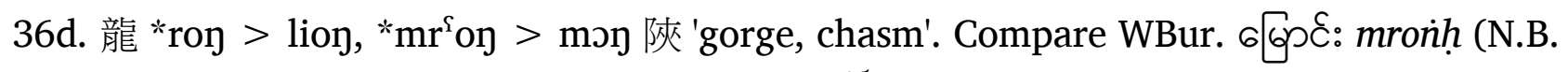
$m r-<$ *mr- or *ml- ) 'ditch, trench' and Tib. ${ }^{2}{ }^{\prime} \cdot$ ron 'ravine' (Zhengzhang 1993: 65).

For the Tibetan, Coblin proposes 然' klun 'stream, valley', which matches less closely both in phonology and semantics (1979: 209 note 60). For the development of rhotics in the Chinese transcriptional dialect see the discussion at 11a-b.

37a. 倫 *run > luin 山 'mountain'. In the transcriptional Chinese dialect -u- had already broken to -uə- before dentals (cf. note 21). Beckwith implausibly proposes Tib. ₹̂̀ $r i$ 'mountain' as a cognate (2008: 107).

37b. 狼 * ${ }^{\mathrm{s}}$ ay > la 高 'high'. Coblin (1979: 209 note 67, also cf. Benedict 1972: 43 note 140) and Zhengzhang (1993: 65) compares OBur. 6) mrañ? 'high'; compare Tan. 在 bjij $^{1}<$ *mbjay < *mbrjay < *mrjay, and Japhug Rgy. mbro (Jacques 2014: 176177). Ma \& Dai (1982: 24) identify the Bailang word with 山 'mountain', and offer comparisons such as Jinghpaw $l a \eta^{31}$ (also cf. Xu et al. 1983). For the development of 
rhotics in the Chinese transcriptional dialect see the discussion at 11a-b.

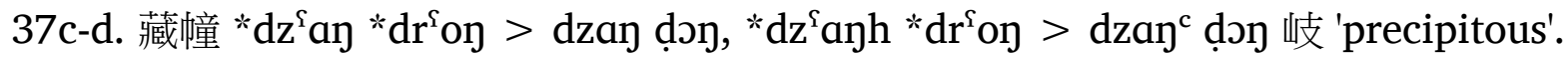

Coblin (1979: 200) and Zhengzhang (1993: 65) compare the first word with Tib. ग/5 "

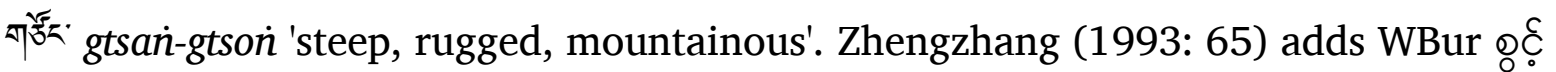
cwain? ( $<*$ dzon?) 'lofty' and compares the second word with WBur. 600sc thon (N.B. -on $<$ *un்) 'set upright, raise up'.

38a. 扶 *ba $>$ bua, * ${ }^{\mathrm{h}} \mathrm{a}>\mathrm{p}^{\mathrm{h}} \mathrm{a},{ }^{*} \mathrm{pa}>$ pua 緣 'follow along the edge'.

38b. 路 “ $\mathrm{r}^{\mathrm{S}} \mathrm{aks}>1 \mathrm{a}^{\mathrm{c}}$ 崖 'cliff, precipice'. Tib. 顽' brag 'cliff'. The early date of cluster simplification (see discussion at $4 \mathrm{~b}$ ) suggests that this character was read /rah/ in the transcriptional dialect, in which case the comparison with the Tibetan is not compelling. However, the identification of Turkic qüngïraq with the Xiongniu sword called transliterated 徑路 in the Hanshu (and 輕呂 in the Yi Zhoushu) suggests that 路 may have had a rusheng reading " ${ }^{\mathrm{f}} \mathrm{aks}>$ lak (see Pulleyblank 1962: 222, Schuessler 2014: 253, and de la Vaissière 2003: 129). Zhengzhang (1993: 65) accepts the qusheng reading and compares Tib. ' 2 ' 'mountain pass'.

38c. 側 *tsrək > tṣik! 'large stone' (?). On the development of OChi. *-ə- in the Chinese transcriptional dialect see discussion at 13a.

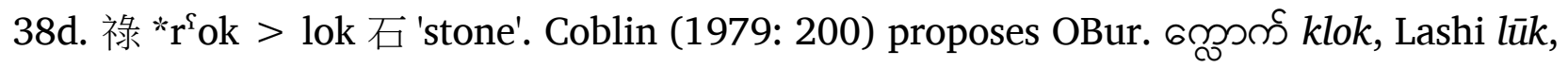
Mikir lòk, Ahi lu ${ }^{44}$ as cognates; Ma \& Dai (1982: 24) repeat the Burmese comparison and offer additional apparently related words in other languages. In addition to the Burmese form, Zhengzhang (1993: 65) also compares OChi. 礫 lek $<*[r]^{\text {` }}$ ewk (1728/1125j) 'pebbles'. See discussion at $11 \mathrm{a}-\mathrm{b}$.

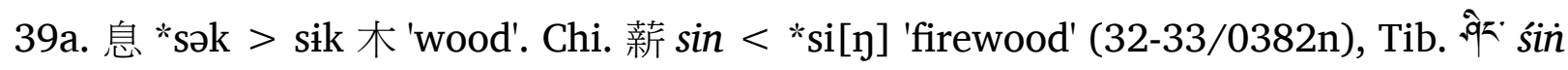
'wood', Bur. כొઈీ sac < *sik 'tree' (Lashi sə:kH), Tan. 荻 $\mathrm{sji}^{1}<{ }^{1}$ sje < *sjeN (4250) 'bois, arbre' (also cf. Ma \& Dai 1982: 24, Zhengzhang 1993: 65). For the potential import of this word in the sub-grouping of Bailang within the Trans Himalayan family see discussion at 28a. On the development of OChi. *-ə- in the Chinese transcriptional dialect see discussion at 13 .

39b. 落 * $\mathrm{r}^{\mathrm{f}}$ ak > lak 薄 'thicket'.

39c. 服 *bək > buk, bə? > bu 發 'send forth, bring forth'. Coblin compares a䇃” hphro 'scatter, emanate' (1979: 209 note 40). The lack of final -g in Tibetan and medial -r- in Bailang are both problems for such a comparison. Zhengzhang (1993: 65) compares Bur. ৩ฮ์ pac 'throw, shoot'. ${ }^{67}$ On the development of OChi. *-ə- in the Chinese

67 One may perhaps see here a word related to Bailang 辟 * $\mathrm{b}^{\mathrm{s} e k}>$ bek, bek $>$ biek, pek > piek 涉 'traverse' (25a) and compare Limbu pekma 'go' (Michailovsky 2002), as above. 
transcriptional dialect see discussion at 13a.

39d. 淫 *ləm > jim 家 'home, family'. Chi. 窨 'imH < *q(r)[ə]m-s (653-) 'subterranean

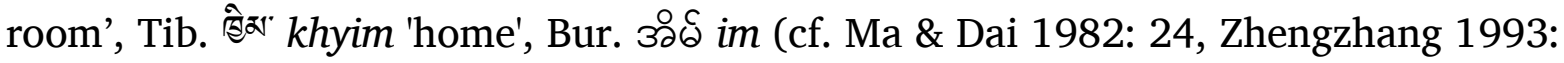

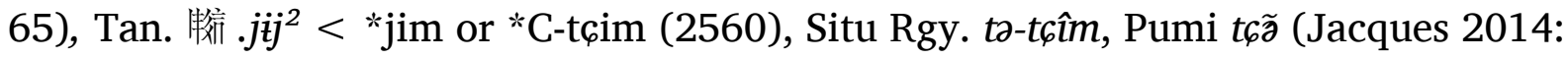
186). These comparisons ensure that *l- in type B syllables had already changed to jby the time of the Chinese transcriptional dialect. However, the comparison of Bailang 潭 *1 $1^{\text {S }}$ mm > dəm 甘 'sweet' (8b) with Chi. 甜 dem < *1 em (36-16/0621-) 'sweet' etc. shows that type A * $1^{\text {s }}$ - had not yet changed to $d$ - in the transcriptional Chinese dialect, and the comparison of Bailang 潯 *s-ləm 溫 'warm' (23b) to Bur. ㅇํ lum 'warm' etc. means that *s-1- had not yet become $z$ - in the transcriptional dialect. These pieces of evidence support Baxter \& Sagart claim that *1- > y- "was the first to occur" (2014a: 109 also cf. Sagart 1999: 30-31). ${ }^{68}$ On the development of OChi. *-əin the Chinese transcriptional dialect see discussion at 13a.

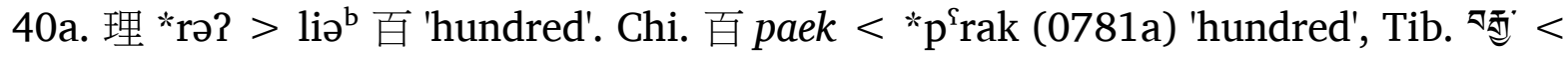
OTib. 鸣 *r-ja (2798), Japhug Rgy. zurza <*wə-rja (Zhengzhang 1993: 65, Jacques 2014: 92). Beckwith sees the Bailang form as particularly close to Lolo-Burmese (2008: 95, 107), but this is because he follows Matisoff (2003) in projecting the epenthetic -g- of the Tibetan form into the proto-language. According to Li's law this -g- is an Tibetan innovation (Li 1959). Recall that the Bailang word for 'hundred' is potentially better compared to the bound Japhug Rgy. classifier -ri 'one hundred' and its cognates, such

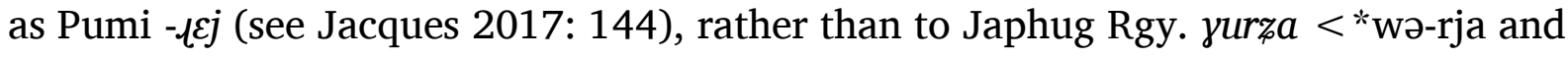
its cognates given immediately above. For the development of rhotics in the Chinese transcriptional dialect see the discussion at 11a-b. On the development of OChi. *-əin the Chinese transcriptional dialect see discussion at 13a.

40b. 曆 " $\mathrm{r}^{\mathrm{S}} \mathrm{ek}>$ lek 宿 'overnight stay'. Chi. 夜 yaeH < *N.rak-s (0800j) 'night', Tib. 町

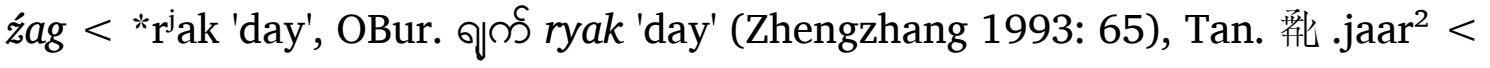
*r-jaak (0811), Japhug Rgy. tr-ræab 'une nuit' (cf. Jacques 2014: 135 for discussion of the Japhug form).

40c. 鬁 *tse > tsie 到 'reach, arrive at'. Zhengzhang (1993: 65) compares OChi. 至 tsyijH

68 Sagart (1999: 31) points out that in the 後漢書 Hòu Hànshū, the same text that preserves the Chinese translations of these poems, the Japanese word Yamato is transcribed 邪馬台 zjae-maeX-doj. If the initial 邪 zjae which suggests the lateral cluster *s-1- had already changed. However, Baxter and Sagart now reconstruct a uvular origin *sə.GA for 邪 zjae, so this observation is not of direct relevance for the dating of changes to laterals. 
$<$ *ti[t]-s (29-15/0413a) 'arrive'.

40d. 雒 * $\mathrm{r}^{\mathrm{S}} \mathrm{ak}>$ lak 洛 'Lo-yang'. A loan from Chinese 洛 ${ }^{*} \mathrm{r}^{\mathrm{f}} \mathrm{ak}>$ lak. Coblin notes that both characters are used to spell this word in Chinese.

41a. 捕 * $\mathrm{b}^{\mathrm{f}} \mathrm{as}>\mathrm{ba}^{\mathrm{c}}$ 父 'father'. Chi. 父 bjuX <*[b](r)a? (01-67/0102a), Tib. " pha, Bur. $\theta$ pha 'father' (cf. Ma \& Dai 1982: 24, Zhengzhang 1993: 65).

41b. 茞 *gin > gin 子 'son'. ${ }^{69}$

41c. 菌 *gun? > guin ${ }^{\mathrm{b}}$ 同 '(some, together $=$ ) altogether'. This word is also glossed 菌 "gun? > guin ${ }^{\mathrm{b}}$ 人 'people, men' at 20b and 部 'tribe' at 24a. See discussion at 20b.

41d. 毗 *bi > bi 賜 'give'. See discussion at 7b.

42a. 懷 " gr ${ }^{\mathrm{S}}$ ui > yuci 懷 'cherish'. In the transcriptional Chinese dialect -ui had already broken to -uəi (cf. note 21). A loan from Chinese.

42b. 稿 * $\mathrm{k}^{\mathrm{f}} \mathrm{au}$ ? $>\mathrm{kau}^{\mathrm{b}}$ 抱 'embrace'.

42c. 匹 ${ }^{*} \mathrm{p}^{\mathrm{h}}$ it $>\mathrm{p}^{\mathrm{h}}$ it 匹'roll'. A loan from Chinese.

42d. 漏 * $\mathrm{r}^{\mathrm{s}} \mathrm{oh}>1 \mathrm{o}^{\mathrm{c}}$ 帛 'silk'.

43a. 傳 *dron > dyæn 傳 'transmit'. Also occurs at 33c.

43b. 室 *lit (*s.ti[t] acc. to Baxter *\& Sagart 2014b) > sit 告 'tell'. Compare Japhug Rgy.

ti (past tut), Tangut 猨 $t$ shjij ${ }^{1}<*$ tshjeej (5612) 'speak'. The proposal of these cognates suggests that OChi. *s.t- had not yet changed to sy- (Baxter \& Sagart 2014a: 135).

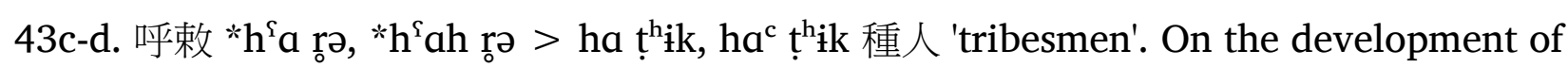
OChi. *-ə- in the Chinese transcriptional dialect see discussion at 13a.

44a. 陵 *rəy > lin 長 'long'. See discussion at 13d.

44b. 陽 *lan > jay 願 'desire'. See discussion at 13a.

44c. 臣 *gin > dźin 臣 'subject'. A loan from Chinese.

44d. 僕 *b $\mathrm{b}^{\mathrm{f}} \mathrm{ok}>$ bok 僕 'servant'. A loan from Chinese.

\subsection{End rhyme in the Bailang songs}

Beckwith notes the implicit understanding of previous scholarship (cf. Dong 1937: 10, Coblin 1979: 169) that the Bailang songs are unrhymed, objecting that the "songs themselves do in fact rhyme, and they do so in extremely intricate, artistic ways. This is actually the most significant linguistic point about the texts" (2008: 89). Beckwith emphasizes the methodological inadequacies of traditional Chinese phonological

69 Zhengzhang (1993: 65) reads 苴 *tsha > tshia (01-57/0046t), which allows him to propose the reasonable looking cognates Bur. ऽ๖: sāh, Tib. ळ’ tsha 'grandson', and Chi. 子 tsiX < *tsə? (0447/0964a). 
reconstruction and also stresses that the Bailang language would have had a phonological system distinct from Chinese and it is only with respect to Bailang phonology that one can judge whether the poems rhyme. Unfortunately, Beckwith says very little about his own methodology in reconstructing Bailang phonology; his finding are concomitantly difficult to confirm.

Here I present and discuss the Bailang rhyme words (i.e. the phonological material represented by the character standing at the end of each line of verse), marshaling those discoveries presented so far about the phonology of the Chinese transcriptional dialect, and to a lesser extent to Bailang phonology itself.

For chronological reasons one can assume that the pronunciation of the transcriptional dialect was closer to Han Chinese than to Old Chinese. Thus, I take Schuesser's Han Chinese as a starting point. In several respects the transcriptional dialect is more conservative than Han Chinese, in particular initial $r$ - had not yet become 1- (see discussion at 11a-b) and '-r- coloring' had not yet taken place (see p. 8). The ensuing discussion makes these changes to Schuessler's Han Chinese in the presentation of the Bailang rhyme words.

End rhyme is most clear in the second poem. The rhyme words in this poem are: 尼 $\mathrm{nei}^{\mathrm{c}{ }^{70}}$ 悟 $\mathrm{ja}^{\mathrm{c}}$ 旅 $\mathrm{lia}^{\mathrm{b}}$ 雒 rak 諾 nak 洗 ser 藩 par 螺 ruai 漓 riai 推 $\mathrm{t}^{\mathrm{h}} \mathrm{uji}^{71}$ 險 $\mathrm{hriam} / \mathrm{hiam}$ 柳 ruib 德 tək 摸 ma. The apparent rhyme of 洗 ser with 尼 nei and 藩 par with 螺 ruai and 漓 riai suggests that *-r changed to $-i$ in the eastern dialect of the capital (Baxter \& Sagart 2014a: 264-271). ${ }^{72}$ If we accept the $-r>-i$ hypothesis the rhyming pattern is A, B, B, C, C, A, D, D, D, E, X, E, X, B. It is tempting to suggest further improvements, e.g. suggesting that 德 tək rhymes with 雒 rak and 諾 nak, but this would be imprudent without further evidence. $^{73}$

A look at the end rhymes in the first poem, now assuming *-r $>-i$, yields the

70 The alternative reading ṇi makes for worse rhyming.

71 The alternative reading tś ${ }^{h} u i$ makes for worse rhyming.

72 The first Chinese poem also provides some evidence for the change ${ }^{*}-\mathrm{r}>-\mathrm{i}$ (see note 21). These syllables may all have been pronounced -r in Bailang. If, as hypothesized here, *-r had changed to $-i$ in the transcriptional dialect, it would have no means of differentiating Bailang -r and Bailang -i.

73 Beckwith reconstructs the end rhymes as: 尼 *ni, 悟 *na, 旅 * rja, 维 *r/la?, 諾 *nra?, 洗 *sar, 藩 *par, 螺 *r/laj, 漓 *r/laj, 推 * ${ }^{\mathrm{h}} \mathrm{wi}$, 險 kẽw, 柳 r/lew, 德 ta?, 摸 ma?, with the pattern ABBCCDDEEAFFCC (2008: 104). To me the rhyme of 險 hriam/hiam with 柳 ruib seems quite unlikely. The suggestion that 德 tək and 摸 ma rhyme is not quite so implausible, but I am uncomfortable saying that all -k were lost in the transcriptional dialect (or in Bailang); some cognates (in particular Bailang 莫 * $\mathrm{mr}^{\mathrm{s}} \mathrm{ak}>\mathrm{mæk},{ }^{*} \mathrm{~m}^{\mathrm{s}} \mathrm{ak}>$

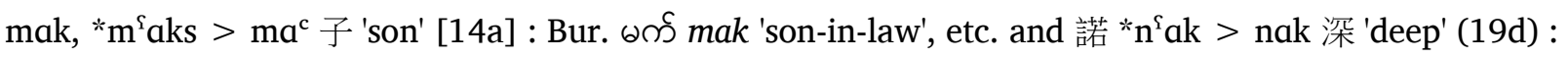
Bur. इर् nak 'deep', etc. suggest the maintenance of *-k. 
following final words: 構 $\mathrm{ko}^{\mathrm{c}}$, 糟 tsou, 脾 bie, 留 riu, 旅 ria ${ }^{\mathrm{b}}$, 艾 yas/yias, 䋠 $\mathrm{pa}^{\mathrm{b}}$, 遠 $\mathrm{wai}^{\mathrm{c}} / \mathrm{p}^{\mathrm{b}}$, 便 briai $\left({ }^{c} /{ }^{b}\right)^{74}$, 離 riai $\left({ }^{c}\right)$, 洞 $\mathrm{do \eta}^{\mathrm{c}}$, 由 jiəu, 鱗 rin (see comm. to 13a), 存 dzəi. These words yield a rhyme pattern: X, A, X, A, B, B, B, C, C, C, X, A, X, X. Again one could suggest further improvements, in particular that 存 dzəi rhymed with 遠 wai ${ }^{\mathrm{c}} / \mathrm{b}$, 便 briai $\left.^{\mathrm{c}} \mathrm{C}^{\mathrm{b}}\right)$, and 離 riai $\left({ }^{c}\right)$, but it is not clear this would be prudent. ${ }^{75}$

The rhyme patterns of the third poem are less obvious. The rhyme words are: 儀 Điai, 憐 ren, 犁 rei/ri, 沐 mok, 微 mui, 拒 $\mathrm{gia}^{\mathrm{b}} / \mathrm{kya}^{\mathrm{b}}$, 仁 ńin, 龍 rioy/mroy, 幢 droy, 祿 rok, 淫 jəm (see comm. to $13 \mathrm{~b}$ a) 雒 rak, 毗 bi, 漏 ro $^{\mathrm{c}}$, 敕 $\mathrm{t}^{\mathrm{h}} \mathrm{ik}$, 僕 bok. Looking just at the codas we have: -ai, -en, -ei/-i, -ok, -ui, -a, -in, -oj, -oy, -ok, -əm, -ak, -i, -o, -ik, -ok. In their Han Chinese garb they do little more than suggest that the poem might have been intended to rhyme. In some cases the Old Chinese readings would improve the rhyming. For example, the Old Chinese readings 憐* ${ }^{\varsigma}$ in and 仁 *nin rhyme, but their Han equivalents 憐 ren and 仁 ńin do not. I am able to offer no further insight on the rhyming patterns of the third poem. ${ }^{76}$

Beckwith appears to be correct that the Bailang poems rhyme. Nonetheless, much remains murky, and the temptation to alter our interpretation of Bailang phonology to improve rhyming further, although it would be defensible if there were a clearly structured rhyme pattern, is methodologically dangerous, and here avoided. More extensive research is required to improve our understanding of Bailang rhyming.

\section{Conclusions about Chinese phonology}

This study permits the conclusion that the transcriptional Chinese dialect had already undergone the following changes.

'final cluster simplification' (Baxter 1992: 568) (see comm. to 4b)

'rounding diphthongization' (Baxter 1992: 566-567) (see p. 7)

74 Following the discussion at (8d) and (14d), I take 遠 *wans $>$ wan $^{\mathrm{c}}$, *wan? $>\mathrm{wan}^{\mathrm{b}}$, 便 *ben $>$ biæn, and 存 $* \mathrm{dz}^{\Upsilon}$ ən $>\mathrm{dz}$, to have originally had final $-\mathrm{r}$.

75 The A rhymes are somewhat more straightforward in Old Chinese (糟 * ${ }^{\mathrm{s}} \mathrm{u}$, 留 *ru, 由 *ju) than in Han Chinese (糟 tsou, 留 riu, 由 jiəu) perhaps suggesting that the relevant changes had not yet occurred. Beckwith gives the end rhymes as 構 *kew, 糟 *tsew, 脾 *bi, 留 *r/lew, 旅 *r/la?, 艾 *ni, 䋠 *pa, 遠 *war, 便 *bjar, 離 *r/li, 洞 *dẽw, 由*l/jew, 鱗 *r/lin, 存 *dwin (2008: 97) to yield a pattern AABACACDDBAAEE. The key hypotheses are that *u and *o had changed to *ew and that nasalization was (in some cases?) super-segmental.

76 Beckwith reconstructs the rhyme words of the third poem as: 儀 *nei, 憐 *rin, 犁 *r/lei, 沐 *mo?, 微 *mui, 拒 *gjo, 仁 *njin, 龍 *r/lẽw 幢 *drẽw, 祿*r/lo?, 淫 *jẽw, 雒 *ra?, 毗 *bei, 漏 *r/lo, 敕 *r/lei 僕 *bo?, which leads to a pattern ABAC ADBE ECEF ADAC (2008: 105). 
*1- > j- in type B syllables (Baxter 1992: 197) (see comm. to 39d)

-r > -i (Baxter \& Sagart 2014a: 264-271) (see p. 42)

The transcriptional dialect had not undergone these changes.

$1^{\text {s }}$ - > d- in type A syllables (Baxter 1992: 197) (see comm. to 39d)

r > 1- in both type A and type B syllables (Baxter \& Sagart 2014a: 110) (see comm. to $11 \mathrm{a}-\mathrm{b})$

sə.1- > zy- (Baxter \& Sagart 2014a: 191) (see comm. to 39d)

'r-color' (Baxter 1992: 573-574) (see p. 8)

Evidence of erstwhile *-r, whether from the rhyming of the Chinese poems, the Bailang poems, or the etymological connections of Bailang words, is available for readings of the following characters.

端 twan $<* t^{\mathrm{f}}$ or $(25-24 / 0168 \mathrm{~d})$ (p. 13, n. 38)

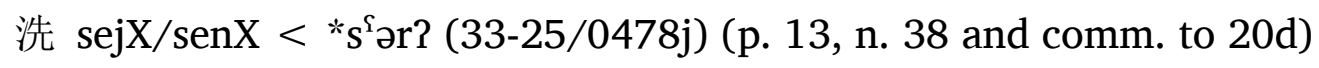

藩 pjon < *par (24-54/0195s) (p. 13, n. 38)

飛 pjij < *Cə.pə[r] (27-09/0580a) (p. 13, n. 38)

便 bjienH $<*$ *b]e[n]-s (23-25/0221a) (see comm. to 9d)

存 dzwon $<*[\mathrm{dz}]^{\text {` } \partial[\mathrm{n}]}(33-22 / 0432 \mathrm{a})$ (see comm. to $14 \mathrm{~d}$ )

遠 hjwonX < *C.G ${ }^{\mathrm{w}}$ an? (25-15/0256f) (see p. 43, n. 74 and comm. to 8d)

Miscellaneous conclusions include that $大$ 'big' is perhaps better reconstructed in Old Chinese with initial $* d^{\text {s }}$ - than with initial $* 1^{\text {s }}$ - (see comm. to $1 \mathrm{a}$ ) and that the irregular phonetic development of 存 (i.e. * $\mathrm{dz}^{\text {〔}}$ ən $>$ dzən and not dzen, see Baxter 1992: 431-432) took place in the history of the transcriptional dialect, and preceded the change of *-r $>\mathrm{i}$ (or $-\mathrm{n}$ in the dialect ancestral to MChi.); see comm. to 13a.

\section{The sub-grouping of Bailang}

As Coblin summarizes, there is a tradition of seeing Bailang as a member of Lolo-Burmese, or at least closely affiliated with the Loloish (or Naic) languages (1979: 197). Coblin appears to take this hypothesis for granted in his search for cognates rather than arguing for it explicitly.

Beckwith sees the Bailang word 理 *rə? > liəb 百 'hundred' (40a) as particularly close to Lolo-Burmese (2008: 95, 107), but this is because he follows Matisoff in projecting the epenthetic -g- of the Tibetan form into the Trans-Himalayan proto-language. According to Li's law this -g- is an Tibetan innovation (Li 1959). The Bailang form just as close to Tib.

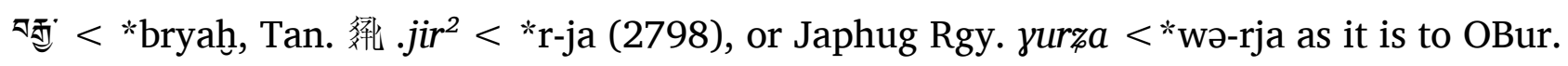
๑ $r y \bar{a}$. As noted above, potentially the Bailang word belongs to a wholly different 
etymon, namely the etymon seen in Japhug Rgy. -ri 'hundred'. The Bailang first person pronoun 支 *ke $>$ kie $>$ tśe J 'we, us' (4c) weighs against an affiliation with LoloBurmese, since velar (or uvular) initial first person pronouns are absent in this subbranch, although they are widespread across the Trans-Himalayan family in general.

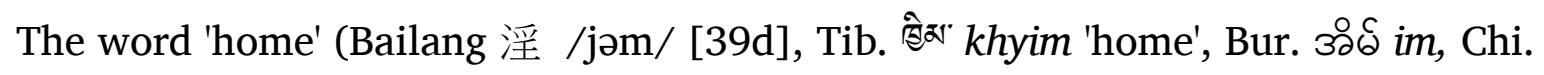
* $\mathrm{q}(\mathrm{r})[ə] \mathrm{m}-\mathrm{s}$ 'subterranean room') offers better evidence for a close tie between Bailang and Lolo-Burmese. Sagart suggests that in such correspondences the Chinese uvular is original and that it develops a velar in Tibetan and is lost in Burmese (2006: 212). The loss of uvulars is thus a potential isogloss that unites Bailang and Burmese. However, taken alone this is not compelling evidence for subgrouping.

One might be tempted to look at those word in which Tibetan -in corresponds to Burmese - $a c<*$-ik, such as 'heart' and 'wood', for a clue to which language Bailang appears closer to. However, such an investigation yields the curious result that in the word 'heart' (Bailang /nəy/ [28a]. Chi. ] nyin < *nin (32-28/0388f) 'kindness', Tib.

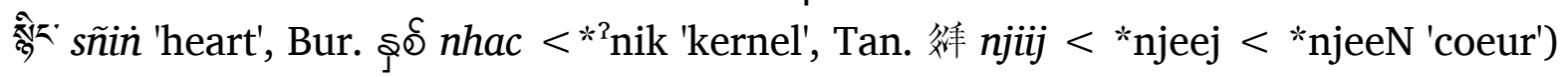
Bailang patterns with Tibetan in having a velar nasal final rather than a velar stop final, but in the word' "sək > sik o 'wood' (39a) the velar stop final of Bailang patterns with the Burmish languages (Bur. כ0ঠీ sac < *sik 'tree', Lashi sa:kH) against the velar nasal of

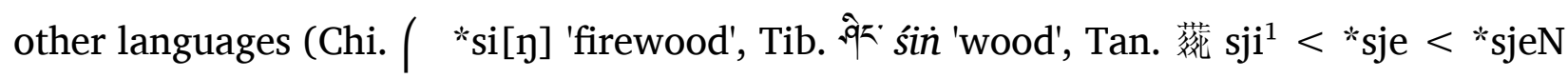
[4250] 'bois, arbre'). The conclusion appears inescapable that variation between *ik and *in in these words, probably of a morphological nature, was present already in the protolanguage.

\section{Abbreviations}

Bur. Burmese

Chi. Chinese

MChi. Middle Chinese

OBur. Old Burmese

OChi. Old Chinese

Rgy. Rgyalrong (apud Jacques 2014)

Tan. Tangut (apud Jacques 2014)

Th. Thangmi (apud Turin 2012)

Tib. Tibetan

WBur. Written Burmese 


\section{Primary sources}

Hou Han shu 後漢書 (Book of the Later Han). 120 juan, compiled by Fan Ye 范曄 (398446), completed between 433 and 445. Beijing: Zhonghua shuju 中華書局, 1965. This edition includes the commentary written in the name of Li Xian 李賢 (651-684), which was presented to Emperor Gaozong 高宗 of the Tang on 11 January 677. Mdz. Mdzañs blun źes bya baḥi mdo (Derge Kanjur, vol. 74, pp. 29a-298a) Mila Mi la ras pahi rnam thar (de Jong 1959)

\section{References}

Baxter, William H. (1992). A Handbook of Old Chinese Phonology. Berlin: Mouton de Gruyter

Baxter, William H. and Laurent Sagart (2014a). Old Chinese: A New Reconstruction. Oxford: Oxford University Press.

Baxter, William H. and Laurent Sagart (2014b). The Baxter-Sagart reconstruction of Old Chinese (Version 1.1). Online at http://ocbaxtersagart.lsait.lsa.umich.edu/.

Beckwith, Christopher I. (2008). "The Pai-lang songs: The earliest texts in a TibetoBurman language and their Late Old Chinese transcriptions." Medieval Tibeto-Burman Languages III. Christopher Beckwith, ed. Halle: International Institute for Tibetan and Buddhist Studies GmbH: 87-110.

Benedict, Paul (1972). Sino-Tibetan: A conspectus. Cambridge: Cambridge University Press. Bodman, Nicolas C. (1980). 'Proto-Chinese and Sino-Tibetan: towards establishing the nature of the relationship.' Contributions to historical linguistics: Issues and methods. Frans van Coetsem and Linda Waugh (eds.), Leiden: Brill, 34-199.

Bradley, David (1975). "Nahsi and Proto-Burmese-Lolo". Linguistics of the Tibeto-Burman Area 2.1: 93-150.

Bradley, David (1979). Proto-Loloish. London: Curzon Press.

Coblin, W. South (1979). "A New Study of the Pai-lang Songs." Tsing Hua Journal of Chinese Studies 12: 179-216.

Coblin, W. South (1987). "A Note on Old Tibetan Mu." Linguistics of the Tibeto-Burman Area 10.1: 166-168.

Dong Zuobin 董作賓 (1937). 漢白狼王歌詩校考 Han Bailangwang geshi jiaokao. 邊疆半月 刊 Bianjiang banyuekan. Reprinted in 平盧文存. Pinglu wencun. Taipei: 1963, Vol 2. juan 5, pp. 7-14. 
van Driem, George (2014). "Trans-Himalayan.” Trans-Himalayan Linguistics. Thomas

Owen-Smith and Nathan W. Hill, eds. Berlin: Mouton de Gruyter. 11-40

Goldstein, David M. (2015). (Review of Baxter \& Sagart 2014). Bulletin of the School of Oriental and African Studies 78.2: 413-414.

Handel, Zev (2008). "What is Sino-Tibetan? Snapshot of a Field and a Language Family in Flex." Language and Linguistics Compass 2.3: 422-441.

Harbsmeier, Christoph (2016). 'Irrefutable Conjectures. A Review of William H. Baxter and Laurent Sagart, Old Chinese. A New Reconstruction.' Monumenta Serica 64.2: 445504.

Hill, Nathan W. (2007). “Aspirated and Unaspirated Voiceless Consonants in Old Tibetan.”語言暨語言學 / Languages and Linguistics 8.2: 471-493.

Hill, Nathan W. (2012). "The six vowel hypothesis of Old Chinese in comparative context"' Bulletin of Chinese Linguistics 6.2: 1-69.

Hill, Nathan W. (2013). "Relative order of Tibetan sound changes affecting laterals." Language and Linguistics 14.1: 193-209.

Hill, Nathan W. (2014). "Proto-Kuki-Chin initials according to Toru Ohno and Kenneth VanBik." Journal of the Southeast Asian Linguistics Society 7: 11-30.

Hill, Nathan W. (2015). "The Contribution of Tangut to Trans-Himalayan Comparative Linguistics." Archiv orientální 83.1: 187-200.

Hill, Nathan W. (2017). (Review of Baxter \& Sagart 2014). Archiv orientální 85.1: 135-140. Ho Dah-an (2016). 'Such errors could have been avoided.' (Review of Baxter \& Sagart 2014). Journal of Chinese Linguistics 44.1: 175-230.

Jacques, Guillaume (2004). “The laterals in Tibetan.” Presentation at the Himalayan Languages Symposium, Thimphu.

Jacques, Guillaume (2007). "A shared suppletive pattern in the pronominal systems of

Chang Naga and Southern Qiang." Cahiers de linguistique - Asie orientale 36.1: 61-78. Jacques, Guillaume (2014). Esquisse de phonologie et de morphologie historique du tangoute. Leiden: Global Oriental.

Jacques, Guillaume (2015). "Derivational morphology in Khaling." Bulletin of Chinese Linguistics 8: 78-85.

Jacques, Guillaume (2016). "Subjects, objects and relativization in Japhug." The Journal of Chinese Linguistics 44.1: 1-28

Jacques, Guillaume (2017). "The morphology of numerals and classifiers in Japhug." Sociohistorical Linguistics in Southeast Asia: New Horizons for Tibeto-Burman: Studies in honor of David Bradley. Picus Sizhi Ding and Jamin Pelkey (eds.), Leiden: Brill, 135- 
148.

de Jong, Jan Willem (1959). Mi la ras pa'i rnam thar: texte tibétain de la vie de Milarépa. 'SGravenhage: Mouton.

Judson, A. (1893). Burmese-English Dictionary. Rangoon: Superintendent, Government Printing Burma.

Karlgren, Bernhard (1957). Grammata Serica Recensa. Stockholm, Museum of Far Eastern Antiquities.

Konnerth, Linda (2016). "The Proto-Tibeto-Burman *gV nominalizing prefix." Linguistics of the Tibeto-Burman Area 39.1: 3-32.

LaPolla, Randy J. (2003). "Overview of Sino-Tibetan morphosyntax." The Sino-Tibetan. Languages. Graham Thurgood and Randy J. LaPolla, eds. London: Routledge, 22-42. LaPolla, Randy J. and Dory Poa (2001). Rawang Texts. Munich: Lincom Europa.

Li Fang-Kuei (1959). “Tibetan Glo-ba-‘dring.” Studia Serica Bernhard Karlgren dedicata. Søren Egerod, ed. Copenhagen: E. Munksgaard. 55-9.

Li, Fang-Kuei 李方桂 (1971). 〈上古音Ģ 究〉, 《ǒ 華學報》新 9: 1-61。

Li, Fang-Kuei 李方桂 (1974-75). "Studies on Archaic Chinese". Monumenta Serica 31: 21987 (translation of Li 1971 by Gilbert L. Mattos)

Luce, Gordon H. (1985). Phases of Pre-Pagán Burma: Languages and History. Oxford: Oxford University Press.

Lung, Rachel (2011). Interpreters in Early Imperial China. Amasterdam: John Benjamins Publishing Company.

Ma Xueliang 馬學良 and Dai Qingxia 戴慶廈 (1982). 《白狼歌》研究 'Bailangge' yanjiu. 民 族語文 Minzu yuwen 1982.5: 16-26.

Matisoff, James A. (1972). The Loloish Tonal Split Revisited. Berkeley: Center for South and Southeast Asia Studies, University of California.

Matisoff, James A. (2003). Handbook of Proto-Tibeto-Burman: system and philosophy of Sino-Tibeto-Burman reconstruction. Berkeley: University of California Press.

Michailovsky, Boyd (2002). Limbu-English Dictionary. Kathmandu: Mandala Book Point.

Miyake, Marc Hideo (2003). "Philological evidence for *e and *o in Pre-Old Japanese." Diachronica 20.1: 83-137.

Nishida Tatsuo 西田 龍雄 (1957). "チベット語・ビルマ語語彙比較における問題" [Tibetan and Burmese: Some problems concerning the comparison of their vocabularies]. 東方 学 Tohō Gaku 15: 64-44.

Nishida Tatsuo 西田 龍雄 (1977). "Some Problems in the Comparison of Tibetan, Burmese and Kachin Languages". 音声科学研究 Onsei Kagaku Kenkyū (Studia phonologica) 11: 
$1-24$.

Okrand, Marc (1974). "Na-khi and Proto-Lolo-Burmese: a preliminary survey". Linguistics of the Tibeto-Burman Area 1.1: 55-97.

Pulleyblank, Edwin G. (1962). "The Consonantal System of Old Chinese: Part II", Asia Major (New Series) 9: 206-265.

Pulleyblank, Edwin G. (1963). "An interpretation of the vowel systems of Old Chinese and of Written Burmese." Asia Major (New Series) 10.2: 200-21.

Pulleyblank, Edwin G. (1983). "Stages in the transcription of Indian words in Chinese from Han to T'ang". Klaus Röhrborn and Wolfgang Veenker (eds.), Sprachen des Buddhismus in Zentralasiens. Vorträge des Hamburger Symposions von 2. Juli bis 5. Juli 1981. Wiesbaden: Otto Harrassowitz, 73-110.

Sagart, Laurent (1999). The roots of old Chinese. Amsterdam: John Benjamins Pub. Co. Sagart, Laurent (2006). "Handbook of Proto-Tibeto-Burman: system and philosophy of Sino-Tibeto-Burman reconstruction. By James A. Matisoff." Diachronica 23:1: 206223.

Schuessler, Axel (2009). Minimal Old Chinese and Later Han Chinese. Honolulu: University of Hawai'i press.

Schuessler, Axel (2014). "Phonological notes on Hàn period transcriptions of foreign names and words." Studies in Chinese and Sino-Tibetan Linguistics. Taipei: Academia Sinica. 249-292.

Schuessler, Axel (2015). "New Old Chinese.” Diachronica 32.4: 571-598

Starostin, George (2015). (Review of Baxter \& Sagart 2014). Journal of Language

Relationship 13.4: 383-389.

Sun, Jackson T. S. (1993). A Historical-Comparative Study of the Tani (Mirish) Branch in Tibeto-Burman. University of California at Berkeley PhD dissertation.

Turin, Mark (2012). A grammar of the Thangmi language: with an ethnolinguistic introduction to the speakers and their culture. Leiden: Brill.

Thurgood, Graham (1974). "Lolo-Burmese rhymes". Linguistics of the Tibeto-Burman Area 1.1: 98-107.

de la Vaissière, Étienne (2003). "Is There a 'Nationality of the Hephtalites'?" Bulletin of the Asia Institute (New Series) 17: 119-132.

Xu Xijian 徐悉艰, Xiao Jiacheng 肖家成, Yue Xiangkun 岳相昆, and Dai Qingxia 戴庆厦 (1983). 景 汉 辞典 Jing Han cidian. Kunming: 云南人民出版社 Yunnan renmin chubanshe.

Zhengzhang Shangfang 郑张尚芳 (1993). 上古缅歌一《白狼歌》的全文解读. Shanggu 
miange 'Bailange' de quanwen jiedu [Decipherment of the text of the 'Bailange' - Old Burmese songs]. 民族语文 Minzu yuwen 1993, (1): 10-21 and (2): 64-70. 